\title{
Do Institutional Investors Drive Corporate Social Responsibility? International Evidence
}

\author{
Alexander Dyck \\ University of Toronto \\ Karl V. Lins \\ University of Utah \\ Lukas Roth \\ University of Alberta \\ Hannes F. Wagner \\ Bocconi University
}

November 18, 2015

\begin{abstract}
We examine whether institutional investors affect a firm's commitment to corporate social responsibility (CSR) for a large sample of firms from 41 countries over the period 2004 through 2013. We focus on environmental and social aspects of CSR, while controlling for firms' governance levels. We find that institutional ownership is positively associated with firm-level environmental and social commitments. Further, the "color of money" matters. Domestic institutional investors and non-U.S. foreign investors account for these positive associations, while U.S. institutional investors' holdings are not related to environmental and social scores. Similarly, higher scores are associated with long-term investors such as pension funds but not with hedge funds. Evidence from a quasi-natural experiment shows that institutional ownership causes improvements in environmental scores. Overall, our results suggest that institutional investors, in aggregate, use their ownership stakes to promote good CSR practices around the world.
\end{abstract}

Keywords: Corporate social responsibility, institutional investors, responsible investing JEL Classification: G15, G23, G30, M14

We thank Tetyana Balyuk for excellent research assistance. We also thank Denis Sosyura and seminar participants at the University of Michigan for helpful comments and suggestions. 
In signing on to these principles, you are publicly committing yourselves to adopt and live up to them. And you are expressing your intent to channel finance in ways that encourage companies and other assets to demonstrate corporate responsibility and sustainability. In short, you have given a vote of confidence to corporate responsibility - not as a luxury, not as an afterthought, not as a goal to be achieved someday, but as an essential practice today.

Ban Ki Moon, UN Secretary General Speech at the NYSE announcing the UN Principles for Responsible Investment, and pledges of investors with \$2 trillion in AUM to commit to the initiative, April 26, 2006

\section{Introduction}

Many institutional investors tout their attempts to influence publicly traded firms' environmental and social commitments, also known as corporate social responsibility (CSR) practices. For example, as of 2015 , investors with over $\$ 59$ trillion in assets under management around the world have pledged to follow the UN Principles for Responsible Investment (PRI), requiring among other things that they incorporate environmental, social, and governance issues into their investment analysis and decision making and that they are active owners individually and collectively regarding these goals. An important premise behind the push for environmental and social issues to be integrated into the investing process is that these issues may pose substantial risks to individual firms and the ongoing health of economies and society at large. Such concerns may cause institutional investors, who own and will continue to own a large fraction of world equities, to compel managers to lessen these risks.

While statements by institutional investors may generate press coverage, there are also strong arguments for why these investors, in aggregate, might not drive firms to improve their environmental and social $(E \& S)$ commitments. Even if investors perceive benefits of E\&S commitments, it is difficult to share the costs of active engagement, and the resulting free rider problem limits actual engagement. Investors may also be engaging in cheap talk and not follow pledges with actions. If investors perceive firms' E\&S commitments as potentially reducing 
risk-adjusted financial return, then investment managers-who are typically judged on financial returns only - as well as the institutional owners themselves-who have fiduciary duties to focus on financial returns - would be justified in just paying lip service. Further, where disagreement amongst institutional investors exists about the importance of E\&S, firm managers will be less likely to respond to those investors pushing for E\&S changes.

To our knowledge, there exists no large-sample work that tests whether institutional investors influence E\&S commitments of firms around the world. We use recently available E\&S data from Thomson Reuters alongside institutional ownership data from Factset to address this question. Our sample includes 3,277 non-U.S. firms from 41 countries over the period 2004 through 2013. Thomson Reuters provides E\&S data through its ASSET4 platform. They collect firm-level measures of E\&S commitments from annual reports, corporate sustainability reports, NGOs and news sources, and package this information so that institutional investors can easily look at firms' performance for specific E\&S items or categories. From these data we construct aggregate environmental and social scores for each firm-year, and we segment these scores into those that are input based (e.g., policies and procedures) and output based (e.g., tons of pollutants). We also take advantage of proprietary summary scores for E\&S produced by Thomson Reuters that are made readily available to all investors that use their platform.

In our first tests we examine whether lagged institutional ownership affects firms' current E\&S scores, controlling for observable factors that may affect E\&S directly. We find that when prior-year institutional ownership is higher, firm-level E\&S scores are higher in the subsequent year. Not only is this result statistically significant, it is economically meaningful. For instance, a move from the first to the third quartile in institutional ownership is associated 
with a $5.3 \%$ increase in environmental scores and a $2.7 \%$ increase in social scores. Further tests show that institutional owners impact E\&S scores by influencing policies and procedures (inputs) rather than measured outputs. The same interquartile change in ownership increases environmental and social input scores by $11.5 \%$ and $8.6 \%$, respectively. These findings are consistent with institutional owners believing that it is important to pressure firms to improve their current E\&S policies in order to achieve long-term benefits. We also find that the impact of institutional ownership is greater for firms with below-median starting E\&S scores, indicating that institutional investors can be particularly effective at promoting changes in firms with the greatest scope for improvement.

To address the possibility that these results are driven by some unobserved firm characteristics that affect both institutional ownership and the willingness of firms to adopt E\&S policies, we introduce a firm-fixed-effect specification as suggested by Gormley and Matsa (2014). Our main results are unaffected when using firm fixed effects - institutional ownership continues to have a statistically significant impact on E\&S scores. In these tests we continue to find that the impact of institutional ownership is greater on environmental than social scores, and is associated with improved policies and procedures rather than measured output scores.

Next, we take advantage of a quasi-natural experiment provided by the BP Deepwater Horizon oil spill in 2010 to bolster our confidence that institutional investors are behind firms' E\&S policy improvements. This environmental disaster represents an unexpected shock that increased the importance of having in place robust environmental policies and procedures, particularly for firms in oil and gas extraction and extractive industries in general. If institutional ownership drives changes in firms' environmental policies, then we would expect 
that firms in these industries which happen to have greater institutional ownership at the time of the shock will be more reactive in the years following this shock. We find precisely this result. In addition to this quasi-natural experiment, Granger causality tests show that lagged institutional ownership is significantly related to E\&S performance, but lagged E\&S performance is not significantly related to institutional ownership. Thus, our evidence suggests that the direction of the observed effects go from institutional ownership to E\&S performance.

We conduct several robustness tests. While our paper does not focus on firms' corporate governance practices given the large body of work that already exists in this area, a valid concern arises that our results are influenced by a firms' governance or transparency levels. As examples, Ferreira and Matos (2008) and Leuz, Lins and Warnock (2009) find that foreign investors tend to avoid firms with bad transparency and governance, while Gillan and Starks (2003) and Aggarwal, Erel, Ferreira, and Matos (2011) provide evidence that institutional investors change the governance practices of firms from around the world. We introduce measures of governance and transparency into our models and our results are unaffected. Additionally, there might be concerns about the reliability of E\&S reporting by firms from around the world and hence the E\&S scores generated by the database we use. We therefore introduce an alternative E\&S score generated by another data provider (Sustainalytics) and re-estimate our main models, finding similar results albeit with a more limited sample.

Having established that institutional investors collectively are a driver of E\&S, we explore which investors' features predict the greatest E\&S impact. Our data allow us to explore the following characteristics that prior literature has suggested are potentially important: investor type (e.g., pension plan versus hedge fund); whether an investor is foreign or 
domestic; and, the investors' country characteristics (e.g., societal values regarding E\&S issues). Long time-horizon investors are likely more willing to incur the fixed costs today of engaging with firms to address potential E\&S risks. This predicts a greater impact, for example, from pension plans than from hedge funds. We also expect domestic investors to have a relatively greater impact. Their costs of activism may be lower because they are likely to interact on a regular basis with domestic firms and their managers, and thus better understand the levers of change. Finally, we conjecture that the individuals doing the investing are likely to absorb and reflect the preferences of the community in which they live. As an example, Hong and Kostovetsky (2012) show that the political preferences of U.S. fund managers are linked to the social scores of the firms in which they invest. Therefore institutions domiciled in countries that put a premium on E\&S issues may be more likely to use their clout to advocate for such policies and procedures than institutions domiciled in a country with less consensus on these issues.

We find strong evidence that all three characteristics listed above are associated with higher E\&S scores. Pension plan ownership has the greatest positive impact on E\&S scores while hedge fund investment is actually negatively associated with E\&S scores. We find that ownership by institutions domiciled in a firm's home country is strongly positively associated with E\&S scores. The effect is statistically significant but attenuated for foreign institutions. Next, we disaggregate foreign institutional holdings into those of U.S.-foreign and non-U.S.foreign institutions, under the premise that U.S. individuals place a lower weight on, and have more variation in opinion about, the importance of environmental and social policies of firms. By comparing U.S.-foreign and non-U.S.-foreign institutions we then gain insight into whether societal attitudes towards E\&S policies matter for their investors' intensity in driving E\&S 
changes. Non-U.S. investors have a significant impact on the E\&S scores of the foreign firms they own, while U.S. investors have no significant impact on foreign firms’ E\&S scores.

In summary, this paper contributes to the institutional investor literature by showing that these investors, who are increasingly being asked to change firms' E\&S commitments around the world, appear to be doing exactly that. Their impact clearly extends beyond governance. Our paper complements the emerging literature on CSR and institutional investors that has focused mostly on U.S. firms. This literature has explored individual channels through which institutional investors may get involved in changing CSR policies of U.S. firms, such as CSR shareholder proposals and voting (Del Guercio and Tran (2012)) and private engagements on CSR issues (Dimson, Karakas, and Li (2015)). We add to this literature by linking institutional investors directly to firms' E\&S scores, which reflect the overall effect of investors' engagements with their portfolio firms. We find that institutional investors influence input rather than output scores, suggestive of a belief that by changing policies and procedures there will be a long-term impact on output. Our results also show that institutional investors have a greater impact on environmental policies and procedures than they do on social ones. Finally, our paper investigates institutional investors and firms from around the world. This allows us to bring into focus both differences in domestic and foreign institutional pressure and differences between U.S. domiciled investors and others on E\&S policies and procedures.

The remainder of the paper proceeds as follows. In Section 2, we discuss the institutional background behind investors' and firms' practices toward environmental and social commitments. Section 3 describes the data and presents the main summary statistics. Section 4 outlines our empirical strategy and presents the main test results. Section 5 reports robustness tests, and Section 6 concludes the paper. 


\section{Institutional Background}

This section motivates and provides context for our subsequent tests by discussing the rationales for investors, stakeholders, and managers to advocate for E\&S activism, and the trade-offs that investors face between activism and screening on E\&S issues.

\subsection{Rationales for investors, stakeholders, and managers to call for E\&S commitments}

Many institutional investors push firms to make $\mathrm{E} \& \mathrm{~S}$ commitments out of the belief that such commitments may help, or at least do not harm, the financial interests of the investors and their beneficiaries. For example, PGGM (the large Dutch pension plan, $\$ 183$ billion in AUM in 2014) states that "Climate change, water scarcity and safety on the shop floor are examples of factors which can pose a risk to our clients' investment returns. We see taking these factors into account as a natural part of good risk management."

A growing number of studies support this view, finding that corporate social responsibility investments can be valuable for shareholders (see, e.g., Godfrey, Merrill, and Hansen (2009), Ferrell, Liang, and Renneboog (2014), Servaes and Tamayo (2013), Hong and Liskovich (2015), Ioannis and Serafeim (2015), and Lins, Servaes, and Tamayo (2015)), although this conclusion is not unanimous, see, e.g., Cheng, Hong and Shue (2015)). ${ }^{2}$ These financial benefits of $\mathrm{E} \& \mathrm{~S}$ investments are crucial in light of the fiduciary obligations of investors that require financial returns and risks for beneficiaries be paramount in decision making. ${ }^{3}$

\footnotetext{
${ }^{1}$ Responsible Investment Report 2013, PGGM.

${ }^{2}$ Margolis, Elfenbein, and Walsh (2009) and Kitzmueller and Shimshack (2012) provide surveys of the CSR literature.

${ }^{3}$ See, for example, Interpretative Bulletin of the U.S. Labor Department (2015).
} 
Groups other than investors may also be pushing firms towards E\&S commitments, such as employees, suppliers, customers, and NGOs. In comparison, these stakeholders are likely to push firms towards overinvestment in E\&S, since they are not constrained by fiduciary duties. If there are market failures with unpriced externalities from firm activity adversely affecting the environment and society, properly targeted demands for E\&S commitments could be beneficial in helping to correct such market failures. But stakeholders might also seek to protect narrower interests. Labor groups, for example, derive benefits from firm commitments to labor rights such as upholding freedom of association and the effective recognition of the right to collective bargaining.

Finally, a third group that might be pushing for E\&S commitments are firms' managers. Managers might invest in value-maximizing E\&S commitments if they are subject to the scrutiny of external market forces or an effective board. Alternatively, entrenched managers might overinvest in E\&S commitments to maximize private benefits, such as using firm contributions to enhance their social status.

\subsection{Investor strategies to address E\&S objectives}

Investors use both screening and engagement strategies to ensure that their portfolios incorporate E\&S issues. Screening strategies can be negative or positive. In negative screening, investors avoid firms that score poorly by E\&S metrics, usually screening out firms by industry and/or by geography. While an increasing number of mutual funds rely on negative screening (often called socially responsible investing funds), most institutional investors do not, and when they do, they exclude few companies. For example, as of Jan 1, 2015 the Norwegian Global Pension Fund had investments in more than 9,000 firms around the world, and 
blacklisted only 58 firms. ${ }^{4}$ The reason for limiting negative screening appears to be a financial tradeoff. Hong and Kacperczyk (2009) show that excluded stocks have higher expected returns than comparable stocks, while exclusion reduces diversification opportunities, making it difficult for investors with fiduciary obligations to justify such an investment approach.

In more widely accepted positive screening, investors seek to buy firms that have better E\&S practices. Positive screening and ascertaining how well a given firm performs has become easier with the rise of investor platforms that provide E\&S performance data. Positive screening, however, creates potential financial risks that are similar to negative screening. Stocks subject to positive screening may be overpriced if such preferences are reflected in substantial assets under management, and again, screening may limit diversification opportunities.

As an alternative, engagement strategies offer a potentially more attractive way for investors to ensure firms incorporate E\&S concerns. Under this approach, investors do not ex ante limit the firms they will invest in. Instead, they actively engage with firms in their portfolio to ensure that E\&S factors are considered and addressed.

Recent studies of U.S. firms suggest a growing range of engagement efforts. Del Guercio and Tran (2012) document investors sponsoring shareholder proposals for E\&S improvements at U.S. firms, while Dimson et al. (2015) document one socially responsible fund's private engagement efforts, often successful, to push U.S.-based firms to incorporate ESG issues.

\footnotetext{
${ }^{4}$ The Norwegian Global Pension fund blacklists firms that manufacture landmines, cluster munitions, nuclear arms, tobacco, and those that in their view seriously or systematically violate human rights or contribute to severe environmental damages.
} 
Globally, there is anecdotal evidence of investor-led E\&S activism, particularly by global pension plans and sovereign wealth funds. Many such investors produce responsible investment reports, documenting their engagements. Associations of institutional investors engage with domestic firms seeking improvements in E\&S, particularly following significant events that reveal new risks, such as the 2010 Deepwater Horizon disaster or the 2013 Rana Plaza garment-factory collapse in Bangladesh.

Notably, institutional investors' pressure for improved E\&S commitments takes into account that much investing is done through delegated portfolio management. Pension plans increasingly demand that fund managers demonstrate they are tracking E\&S in firms and taking active steps to ensure E\&S issues are addressed. For example, in 2015, somewhat late to the game, CalPERS (the large U.S. pension plan, \$301 billion in AUM) announced it would ask all of its external managers to report on ESG. ${ }^{5}$

Perhaps the most prominent indicator worldwide is that managers with more than $\$ 59$ trillion in AUM have signed up to the UN-sponsored Principles for Responsible Investment initiative (UN PRI) mentioned in the introduction. The UN PRI has received pledges from institutional investors to follow these principles when they invest, including commitments to disclose performance against these principles. The UN PRI notes the focus on engagement, not negative screening, as a defining characteristic. ${ }^{6}$

\footnotetext{
5 "We want the managers to come back to us and articulate the ESG factors [...] which they have reflected in their investment policies, and second, to report to us on how those are not just identified but how those are tracked and integrated into the decision-making process... The prize here would be that, through this process, you get investment managers behind the notion that sustainability issues need to be properly defined, properly tracked and ultimately connected into the risk/return framework that investment is all about.": Anne Simpson, head of Corporate Governance at CalPERS, as quoted in Christopher O'Dea, 'CalPERS to transform ESG to 'data driven mainstay' of investment,' Investments and Pensions Europe, July 9, 2015.

6 "Through their focus on engagement, not divestment, the Principles represent a major milestone in our efforts to root global business in universal values to achieve a more sustainable global economy.": George Kell, executive Head Global Compact Office, in "International Funds Worth \$4 Trillion Now Endorse UN Principles for
} 
Summarizing, the issue we seek to understand in this paper is the extent to which institutional investors actively use their stakes to push firms to make improvements in their commitment to environmental and social issues. To the extent that positive screening is additionally taking place, in which institutions wait until a firm has improved its E\&S commitments before owning it, then there would be less scope for institutional pressure to additionally improve E\&S practices once they become owners because there is less room for improvement. This effect would bias against us finding a significant link between institutional ownership and subsequent improvement in E\&S practices. To the extent that negative screening is taking place, institutions would not even be present and thus could not drive changes in E\&S commitments.

Finally, we note that firm E\&S commitments remain largely voluntary choices of firms, rather than products of regulation. As of 2015, only one third of stock exchanges even provide voluntary guidance to issuers on E\&S reporting. ${ }^{7}$ National mandatory reporting requirements on social and environmental matters have until now been largely limited in scope. ${ }^{8}$ The voluntary nature of firms' E\&S commitments around the world should correspond to dispersion in practices among firms, which adds power to our empirical tests.

Responsible Investment Funds backing the Principles launched by United Nations Secretary General Kofi Annan double in five days", Press Release, UN May 1, 2006.

${ }^{7}$ See Sustainable Stock Exchanges Initiative, "Model Guidance on Reporting ESG Information to Investors," 2015

${ }^{8}$ A notable exception, at the end of our sample period, is the European Union Directive (2014/95/EU) that mandates disclosure of non-financial and diversity information, albeit limited to larger firms. 


\section{Sample and Summary Statistics}

\subsection{Sample construction}

Our paper combines data from several sources. We gather information on firms' CSR practices from the universe of firms covered by the Thomson Reuters ASSET4 ESG database. Investors can access information on firms' E\&S practices from firms' annual reports, from firms' corporate sustainability reports (if available), as well as from firm data collected by NGOs and by credible news sources. Thomson Reuters scours all of these sources and provides easy investor access to this data through their ASSET4 platform that offers environmental, social, and governance (ESG) ratings of large, publicly traded companies for more than 45 countries. This database reports two general types of data, one being a large number of individual data items that capture parameters of the firm's ESG performance, and the other being aggregate and standardized scores of these individual data items. ${ }^{9}$ Investors can easily access both the aggregate scores for any company, as well as the individual data items that contribute to the scores (see Appendix A for screenshots). Some investors focus on the aggregate scores, while others seek to perform their own analyses based on the subcomponents.

Both types of variables are available at annual frequency. Consistent coverage of firms begins in year 2004 for most countries, for some countries coverage only begins in 2007 and 2008. We use data from the first year of coverage through year-end 2013 for our analysis. As the data are line-item based, we construct a variety of variables aimed at assessing the strength

\footnotetext{
9 The ASSET4 ESG Database was first created in 2003. The data we use is based on their most recent optimization released in 2014 which reports raw data only for "strategic" items which were collected beginning in 2003. Thomson Reuters reports that the strategic items were chosen to maximize company coverage, timeliness of reporting, data availability, quality, and perceived materiality for investors.
} 
of a firm's commitment to environmental and social stakeholder objectives as will be discussed next. As mentioned at the outset, our focus is on the "E" and "S" dimensions of ESG.

Regarding the environmental performance of firms, ASSET4 provides 70 individual line items grouped into three broad categories; regarding social performance, ASSET4 provides 78 line items grouped into seven broad categories. The broad categories of environmental performance are 1) Emission Reduction, 2) Product Innovation, and 3) Resource Reduction, while the broad categories of social performance are 1) Community, 2) Diversity of Opportunity, 3) Employment Quality, 4) Health and Safety, 5) Human Rights, 6) Product Responsibility, and 7) Training and Development.

The 148 line items in total provided by ASSET4 contain answers to yes/no (Y/N) questions, answers to double $\mathrm{Y} / \mathrm{N}$ questions, and numeric values. The direction of response indicating a positive environmental or social characteristic is negative for some items and positive for others; for the numeric value line items, better "E" or "S" performance relative to others can come from values that are high, low, or zero. To turn these disparate data items into variables suitable for empirical tests, we transform the answers to the ASSET4 questions and the numeric value fields into cohesive indicator variables such that higher values correspond to better "E" or "S" performance.

More specifically, for questions with a positive direction (i.e., a "yes" answer or a greater number is associated with better environmental or social performance), we translate the answers to $\mathrm{Y} / \mathrm{N}$ questions into $0(\mathrm{~N})$ and $1(\mathrm{Y})$; the answers to double $\mathrm{Y} / \mathrm{N}$ questions into 0 $(\mathrm{NN}), 0.5(\mathrm{YN}$ or $\mathrm{NY}$ ), and $1(\mathrm{YY})$; and the answers to numerical questions into 0 (value is less (or equal) than zero; or value is less (or equal) than the median) and 1 (value is greater than zero; or value is greater than the median). For questions with a negative direction (i.e., a 
"no" answer or a lower number is associated with better environmental or social performance), the opposite coding applies. Additionally, to assess whether there may be differences in the way firms respond to investor pressure for CSR depending on whether it is a policy request or an actual measured output or action, we classify variables into input-based and output-based measures. Input-based measures are related to a firm's policies and processes in place and the firm's disclosure of such policies and processes. Output-based measures are related to a firm's outputs and actions. We report the details of these line items, groupings, and indicator variable calculations in Appendix B and C.

There are many possible ways to aggregate the data. The approach we take for our baseline tests is, for each firm and year, to calculate the sum of these indicator variables for each of the environmental and social categories, and aggregate the category scores to obtain overall environmental and social scores. In addition, we also use the aggregated and standardized scores that ASSET4 provides. These scores are the headline numbers that investors see if they do not conduct their own analysis. ASSET4 refers to these indices as $z-$ scores. While our own aggregate scores provide a stand-alone measure of each firm's social and environmental practices in a given year, the ASSET4 $z$-scores are standardized scores and measure the social and environmental performance relative to all other companies in a given year. ASSET4 also produces a transparency score which is defined as the number of data items reported by the company out of all items tracked as part of the ASSET4 scoring system.

We next obtain from the Factset Ownership database (LionShares) detailed information on the institutional investor holdings of the firms for which ASSET4 reports ESG data. ${ }^{10}$ Factset contains institutional ownership data for a large sample of firms from around the world.

\footnotetext{
${ }^{10}$ This database has been previously used by, for example, Ferreira and Matos (2008), Ferreira, Massa, and Matos (2010), Aggarwal et al. (2011), and Iliev, Lins, Miller, and Roth (2015).
} 
The data cover institutional investors' equity holdings collected directly from fund reports, regulatory authorities (e.g., $13 \mathrm{~F}$ reports in the United States), fund associations in different countries, and the fund management companies themselves. The equity positions reflect stakes over which institutional managers exercise investment discretion. Institutional ownership includes ordinary shares, preferred shares, American Depositary Receipts (ADRs), Global Depositary Receipts (GDRs), and dual listings.

Factset reports a variety of statistics on institutional holdings including the overall ownership stakes of institutions, ownership of domestic, foreign, U.S., and non-U.S. domiciled institutions, as well as holdings data broken down by the type of institutions, for example, insurance and investment companies, pension funds, and hedge funds.

While we rely on ASSET4 as our main data source for firm-level E\&S performance, Thomson Reuters, a US-Canadian firm, is one of several potential providers of such data, with no obvious market leader. Therefore, we also obtain similar E\&S data from Sustainalytics, a competitor of Thomson Reuters, based in the Netherlands. ASSET4 and Sustainalytics both cover publicly traded firms worldwide, both sell their data to institutional investors and other clients, and both collect detailed line-item based ESG data for all firms that they cover. Sustainalytics imposes its own weighting on the various environmental and social factors, and these weights vary across industries, providing an alternative approach to aggregation. For robustness purposes, we match our sample firms with E\&S data from Sustainalytics. Sustainalytics data coverage begins in 2009 and it covers a smaller number of firms, and thus it is less well-suited for our time-series tests.

Finally, we obtain financial statement and stock market valuation data for the firms in our sample from the Thomson Reuters Worldscope and Datastream databases. From 
Worldscope we also obtain each firm's percentage of shares that are closely held, as a measure of the level of control of insiders which we use as a proxy for the degree of insider entrenchment. Our final sample consists of 19,849 firm-year observations and covers 3,277 firms from 41 countries during the period 2004 through 2013.

\subsection{Descriptive statistics}

Table 1 provides summary statistics for our overall indicator variables for environmental performance (based on 70 individual indicators) and social performance (based on 78 individual indicators). In Panel A, we report mean and median scores as well as standard deviations for the entire sample. Section A of Panel A provides statistics for overall environmental performance and its three sub-components. The mean environmental score is 1.062 while the median score is 0.954 , and the standard deviation is 0.603 . Section B of Panel A describes statistics for overall social performance and its seven sub-components. The mean and median social scores are higher (different scaling results from the larger number of components) at 3.615 and 3.574 , respectively. Finally, in section C of Panel A we show the ASSET4 standardized environmental and social performance $z$-scores which have mean (median) values of $53.65(56.15)$ and 52.59 (54.34), respectively.

In Panel B of Table 1, we provide summary statistics for environmental and social performance by industry, for the sample year 2010. For environmental scores, high-performing industries are Public Administration, Manufacturing, Transportation and Public Utilities, and low performers are Mining, Services, Agriculture, Forestry and Fishing. The industries with the highest social performance are Public Administration, Transportation, Public Utilities, and Manufacturing, while the lowest social performance is in Agriculture, Forestry, Fishing, 
Mining, and Services. The relative rankings of industries across environmental and social scores are, as one would expect, somewhat related.

Table 2 provides country-level statistics for environmental and social scores for all 41 countries in the sample. We also show the by-country level of institutional ownership, one of our main explanatory variables. The countries with the highest average environmental performance are all European (France, Finland, and Spain), while the lowest performance is found in Egypt, China, and Hong Kong. Regarding social performance, the highest averages again obtain for European firms (Spain, Portugal, and France), and the lowest scores are for Egypt, China, and Taiwan. By number of yearly observations, the four largest countries in the sample are Japan, the U.K., Canada, and Australia, which together account for $50 \%$ of the total sample. Institutional ownership is highest at around $40 \%$ in Canada, Sweden, and Ireland, and lowest at below 10\% in Colombia, Chile, Malaysia, and Egypt.

We show the time series of environmental and social scores as well as institutional ownership in Figure 1. Since time trends are influenced by sample composition, we show in Panel A plots for a constant panel of firms for which uninterrupted data in all years between 2004 and 2013 are available (805 firms), while Panel B plots scores for a shorter constant panel of firms with uninterrupted coverage between 2009 and 2013 (1662 firms). Both panels show a relatively steady increase of environmental and social scores over time. Institutional ownership also tends to increase over time, and all of our later regressions control for year fixed effects.

In Panel C, we decompose the E\&S performance scores into their input-based and output-based components. Broadly speaking, most of the increase in environmental and social performance over time is due to improvements in input-based scores, while output-based scores improve less. 


\section{The Determinants of Firms' Environmental and Social Performance Scores}

In this section, we present tests outlining the relation between (lagged) institutional ownership and firms' E\&S commitments, provide evidence indicating the directionality goes from institutional ownership to E\&S scores, and show that both the type and domicile of investors matter for E\&S commitments.

\subsection{Baseline results}

Our baseline tests use the following specification:

$$
\log \left(\operatorname{Score}_{i t}\right)=\alpha+\beta X_{i t-1}+\gamma^{\prime} Y_{i t-1}+\lambda_{t}+\Lambda+\varepsilon_{i t}
$$

where the dependent variable is the log of one of the environmental or social scores of firm $i$ in year $t, X_{i t-1}$ is the percentage of institutional ownership in year $t-1, Y_{i t-1}$ are a set of firm-level control variables in year $t-1, \lambda_{t}$ are year fixed effects, and $\Lambda$ are country and industry fixed effects, or firm fixed effects (depending on specifications). ${ }^{11}$ We use the log of E\&S measures to normalize them which helps to simplify $\mathrm{E}$ and $\mathrm{S}$ comparisons as the scores are built from ASSET4 data featuring different numbers and types of line items. ${ }^{12}$ For firm level control variables we use the firm's size as measured by the log of total assets, asset tangibility, leverage, Tobin's $q$, and profitability. We include firm size as prior literature has shown this predicts institutional ownership, and larger firms are subject to more external pressures. Hong, Kubik, and Scheinkman (2013) suggest that financial slack also predicts CSR adoption. Following them, we include leverage and asset tangibility to capture credit constraints, and

\footnotetext{
${ }^{11}$ In terms of timing, E\&S variables reflect data available to ASSET4 analysts that covers the firm's fiscal year thus a score for year 2010, for example, would reflect items that occurred during 2010 as well as information contained in the 2011 company annual report and any 2011 company sustainability reports. Our baseline model with 2010 E\&S scores would have year-2009 right-hand-side variables.

${ }^{12}$ Our main results are unaffected if we use unadjusted scores.
} 
Tobins $q$ and ROA to capture the impact of performance. All right-hand side variables are lagged by one year, and standard errors are clustered by country.

The regression results for our baseline empirical specification (1) are reported in Table 3. Because we seek to understand whether institutional investors drive changes in E\&S performance of their portfolio firms, our variable of interest is the total fraction of a firm's shares owned by institutional investors (Total IO). Panel A and B show results for environmental and social scores, respectively. For ease of exposition, we discuss the findings for each type of E\&S score at the same time.

Column 1 of Panel A shows a positive association between the overall environmental score and (lagged) institutional ownership. The estimated coefficient is statistically different from zero at the $1 \%$ level. Coefficients on the control variables show that firms tend to have better environmental performance if they are larger, have more tangible assets, and have higher Tobin's $q$. Turning to column 1 of Panel B, we find similar results for the determinants of social performance. The overall social score is positively associated with (lagged) Total IO, and the coefficient is again significant at the $1 \%$ level. Control variable coefficients show that higher social performance obtains for larger firms and those with higher $q$ values.

These results on the importance of institutional investors for E\&S scores are not only statistically significant, but they are also economically meaningful. To illustrate, a move from the first to the third quartile in total institutional ownership (0.213) is associated with a 5.3\% increase in environmental scores (calculated as $0.213 \times 0.251$ ) and a $2.7 \%$ increase in social scores (calculated as $0.213 \times 0.126)$.

Results are very similar in columns 2 of Panels A and B, where we use the standardized relative-rank ASSET4 $z$-Scores rather than our compilation of non-normalized individual firm 
E\&S scores. These column 2 results give us confidence that our aggregation approach of equally weighting using hand-construction for our E\&S variables is reasonable as the positive influence on scores that obtains from the presence of institutional investors is significant for both our own aggregate measures and the data provider's aggregate measures.

We next assess the degree to which institutional investors influence firm's policies and procedures, what we term as "inputs", compared to the degree to which they influence the measured line-item outputs (e.g., the actual tons of pollutants omitted or the presence of environmental or social controversies in the media). Results from columns 3 and 4 of Panels A and $\mathrm{B}$ show that total institutional ownership impacts E\&S scores by influencing policies and procedures (inputs) rather than measured outputs. The same interquartile change in institutional ownership of 21.3 percentage points increases scores on environmental and social inputs by $11.5 \%$ and $8.6 \%$, respectively. Output-based environmental scores are not influenced by institutional ownership and the significant but very small coefficient on output-based social scores indicates no economic impact. These results are consistent with institutional owners believing they can best make a long-term difference by forcing firms to change their policies rather than waiting to see whether outputs materially change. It is plausible that going forward from now, with a longer time series, one would also observe a significant association with outputs.

Finally, we consider the three components of environmental performance (Emission Reduction, Product Innovation, Resource Reduction) and the seven components of social performance (Community, Diversity \& Opportunity, Employment Quality, Health \& Safety, Human Rights, Product Responsibility, Training \& Development) separately. It might be the case that only certain aspects behind the aggregate E\&S performance scores respond to the 
presence of institutional investors. We find that this is clearly not the case. Strikingly, improvements in all ten components are linked to the stake of institutional investors, and except for Product Innovation all of them are statistically significant at the $1 \%$ level or better. The impact of institutional ownership therefore appears to be broad and affects a wide and diverse range of firm-specific policies.

We next examine whether institutional investors appear to be using their ownership positions to advocate for E\&S changes in firms that appear to have the greatest scope for improvement, rather than simply advocating for changes across all firms no matter their starting point for E\&S commitment scores. Put another way, do institutions appear to matter most where E\&S scores are particularly lacking? To assess this, we split our sample into two subgroups for each of the E\&S categories, based on sample median scores. The below-median subsamples contain firms that have environmental or social scores below the sample median at the time they enter the sample. The above-median subsamples contain firms that have environmental or social scores above (or equal to) the sample median at the time they enter the sample.

Panels $\mathrm{C}$ and $\mathrm{D}$ of Table 3 report results for these below- and above-median subsamples based on environmental and social scores. We estimate Eq. 1 for each of these subsamples separately, and we use a fully-interacted model to test for differences in coefficients between subsamples. For both the environmental scores and social scores, institutional ownership has a more pronounced effect on improvement in E\&S measures for the below-median compared to the above-median E\&S subsamples. From an economic significance perspective, in Panel $\mathrm{C}$ the interquartile range of Total IO is the same in both low and high E subsamples, at 0.21. Thus, the Total IO coefficients in columns 1 and 5 show that 
the effect of Total IO on environmental scores is more than $60 \%$ larger in the below-median than the above-median subsample. In Panel D, the interquartile range of Total IO is 0.19 in the low S subsample and 0.21 in the high S subsample. The column 1 and 5 coefficients thus show that the effect of Total IO on social scores is more than twice as large in the below-median than the above-median subsample. Further, comparing the coefficient estimates on Total IO between subsamples shows that the differences are statistically significant at customary levels in seven out of eight models. Taken together, these results indicate that institutional investors can be particularly effective at using their ownership stakes to promote positive E\&S changes in firms that are most in need of such changes.

It is possible that our results thus far could be driven by one or more unobserved firm characteristics that affects both institutional ownership and the willingness of firms to adopt E\&S policies. To address this possibility, we next introduce a firm-fixed effect specification as suggested by Gormley and Matsa (2014). Table 4 reports the results of the Table 3 model specifications that now include firm fixed effects. We find that the coefficient estimates of Total IO are generally smaller in Table 4, but this is to be expected as the estimates are relying on time-series variation within firms rather than the likely larger cross-sectional variation. As an example, using the overall environmental score as the dependent variable, the coefficient on Total IO declines from 0.251 (in Table 3, Panel A, column 1) to 0.121 (in Table 4, column 1). Importantly, institutional ownership continues to have a statistically significant impact on E\&S scores. We also continue to find that the impact of institutional ownership is greater on environmental than social scores, and in this specification we find some evidence that Total IO is associated with both improved policies and procedures as well as measured output scores. 
Reverse causality is also a potential concern. To address it, we a) use a quasi-natural experiment and b) perform Granger causality tests to draw conclusions about the direction of causality between institutional ownership and E\&S firm performance. More specifically, in our first tests, we use the BP Deepwater Horizon oil spill on May 24, 2010 as a quasi-natural experiment. This unexpected event serves as an exogenous shock to the importance that institutional investors assign to the environmental performance of firms. While the immediate negative economic effect of the oil spill was on BP, the event arguably would have focused investor attention on all extractive industries, and the potential risks of weak environmental performance even in the most developed countries. If institutional ownership drives changes in firms' environmental policies, then we expect that those firms who happen to have greater institutional ownership at that time will be more reactive to this shock as these institutions are better able to force through policy changes. We find precisely this result.

For our tests, we use a difference-in-differences approach in which our sample consists of observations from the 2009 through 2012 period, in order to have balance on each side of the event. Panel A of Table 5 reports regression results for treated firms only (firms belonging to several categories of extractive industries) for which we estimate:

$$
\begin{gathered}
\log \left(\text { Score }_{i t}\right)=\alpha+\beta_{1} \text { Total IO } O_{i t-1}+\beta_{2} \text { Post Event }+\beta_{3} \text { Total IO } O_{i t-1} \times \text { Post Event } \\
+\gamma^{\prime} Y_{i t}+\lambda_{t}+\Lambda+\varepsilon_{i t},
\end{gathered}
$$

where the dependent variables are measures of firms' environmental performance, Post Event is equal to one for the years 2011 and 2012, and zero otherwise, the coefficient of interest is $\beta_{3}$ for the interaction term of Total IO and Post Event, and all other variables are as in Eq. 1. The extractive industries (treated firms) we consider are defined by two-digit SIC code in column 1 
(SIC 13, Oil and Gas Extraction), by SIC division in column 2 (SIC Division B, Mining), and by Fama-French industry code in column 3 (FF 17, Oil and Petroleum Products).

For all of these extractive industry subsamples, the coefficient estimate of $\beta_{3}$ is positive and significant at the $5 \%$ level or better, indicating that the relation between institutional ownership and firms' environmental commitments has strengthened post-Deepwater Horizon. The results in columns 4 and 5 confirm, in line with our baseline results, that the effect of institutional ownership is on input-based, not on output-based, components of environmental performance.

In Panel B of Table 5, we report difference-in-differences results in which we use our entire sample and estimate a triple interaction coefficient for Total $\mathrm{IO} \times$ Post Event $\times$ Treated Firm to capture the difference of the effect of Total IO for treated relative to control firms post the event. Our findings are very similar, and confirm the positive and significant effect of the unexpected Deepwater Horizon event on the relation between institutional ownership and E\&S outcomes. In unreported results, we do not find such an impact on these firms' social policies, consistent with the environmental shock sharpening institutions' focus on environmental policies rather than social policies, which were not subject to such a shock.

In addition to using the BP Deepwater Horizon Oil Spill event as a quasi-natural experiment, we also perform Granger causality tests to draw conclusions about the direction of causality between institutional ownership and E\&S firm performance. We estimate two sets of regressions. In the first set, we regress E\&S scores on lagged Total IO, lagged E\&S scores, and lagged control variables. In the second set of tests, we regress Total IO on lagged E\&S scores, lagged Total IO, and lagged control variables. Since Granger tests are defined for time series data, and because we use panel data, we also include firm fixed effects to ensure that we only 
exploit within firm time series heterogeneity (see also Cvijanovic, Dasgupta, and Zachariadis (2015)). Consistent with Total IO driving E\&S commitments in firms, we find that lagged Total IO is significantly associated with E\&S performance, however, the opposite is not true, lagged E\&S performance is not significantly related to Total IO. ${ }^{13}$

Taken together, our results in Tables 3 to 5 show that institutional investors play an important role in shaping E\&S commitments in firms across the world. The effects are more pronounced in firms with below-median scores, and our evidence suggests that the direction of the observed effects goes from institutional ownership to E\&S performance.

\subsection{The role of investor type}

We next consider the differences in incentives that different types of institutional owners might have with respect to influencing corporate environmental and social decisions. Prior research on U.S. firms has suggested that institutional owners work through shareholder proposals, shareholder voting, and through private engagements. A consistent theme of this research is that for some investors these policies are more important than for others.

We consider two main dimensions along which institutional owners differ-investment horizon and geographic location. We measure investment horizon by investor type and argue that institutions with long investment horizons, such as pension plans, will care more about the potential benefits and costs of E\&S performance than short-horizon investors. For instance, Casamatta and Pouget (2012) cite the manager of an E\&S focused fund: "The big difficulty is that a lot of the reputational issues and environmental issues play out over a very long period of time $[\ldots]$ and if the market isn't looking at it you can sit there for a very long time on your high

\footnotetext{
${ }^{13}$ Not reported for brevity.
} 
horse saying 'this company is a disaster, it shouldn't be trusted 'and you can lose your investors an awful lot of money...". We follow Ferreira and Matos (2008) and classify investors as insurance companies, investment companies, investment advisors, pension funds, or hedge funds, and separate each firm's total institutional ownership stake into these five categories. Further, we segment based on an investor's geographic location and separate ownership into domestic investors, foreign U.S. investors, and foreign non-U.S. investors, as in Aggarwal et al. (2011).

We report these results in Table 6, where the dependent variables are our measures of environmental and social performance. We find that the positive effect of institutional owners on firm's E\&S scores comes primarily through the stakes held by pension funds and investment advisors, as shown in columns 1 and 4. Interestingly, hedge funds, which by their nature of investment style are typically thought of as short horizon investors, are associated with significantly lower environmental and social performance. Further, we find that greater ownership by institutions domiciled in the firms' home country is strongly associated with E\&S scores. The effect is also statistically significant with foreign institutions, but the affect is attenuated.

Finally, to get a sense of the importance of societal values on institutional investors' approach to E\&S we focus on foreign institutions. We conjecture that institutional investors that are located in countries where there are strong and consistent societal values supportive of strong E\&S policies will reflect these beliefs when they invest abroad. To test this conjecture, we need a measure of societal values. A crude proxy we use in these tests is whether a foreign institution is U.S. or non-U.S., under the assumption that U.S. citizens place a lower weight on 
E\&S factors than investors domiciled in other countries. ${ }^{14}$ Legal rules across countries are also likely to play a role, which also reflect societal values. For example, the U.S. has been seen to have, in international comparison, a more rigorous fiduciary standard. The Labor Department's interpretative bulletin issued in 2008 sought to clarify whether the fiduciary duties of investors allowed them to consider ESG factors and concluded "[...] that fiduciary consideration of collateral, non-economic factors in selecting plan investments should be rare and, when considered, should be documented in a manner that demonstrates compliance with ERISA's rigorous fiduciary standards. The Department believes that in the seven years since its publication, IB 2008-01 has unduly discouraged fiduciaries from considering ETIs and ESG factors." 15

Results reported in Table 6 that differentiate between foreign U.S. and foreign non-U.S. institutional investors show a positive and significant impact for non-U.S. investors only and, interestingly, find no impact of U.S. institutional ownership on E\&S scores. One potential explanation for this result is that there are not strong beliefs among U.S. institutions in aggregate for the importance of firm-level E\&S commitments. Another explanation is that concerns regarding fiduciary duty interpretations have caused U.S. institutions to play it safe.

\section{Robustness and Alternative Performance Measures}

In this section, we undertake several robustness tests to assess whether potential omitted variables or measurement issues might be driving our results. Specifically, we analyse whether the link between greater institutional ownership and improved environmental and

\footnotetext{
${ }^{14}$ Consistent with this conjecture, Franzen (2003) shows that when survey data on citizens' environmental concerns is adjusted for GDP/capita, U.S. environmental concern is substantially below that of other countries (based on ISSP 2000).

${ }^{15}$ Department of Labor, Interpretive Bulletin Relating to the Fiduciary Standard under ERISA in Considering Economically Targeted Investments IB (2015-01)
} 
social scores may be explained by firm-level transparency on these issues or by better overall governance at these firms. We also consider a different measure of environmental and social performance constructed from an alternative data source. We discuss these tests in turn.

\subsection{Disentangling environmental and social performance from transparency and governance}

One potential concern about our results is that unobserved heterogeneity between firms may contribute to the observed positive relation between institutions and E\&S commitments. In the previous section we have addressed this concern with firm fixed effects and evidence from a quasi-natural experiment. It is illustrative, however, to explicitly control for firm-level characteristics that might influence both institutional ownership and E\&S performance at the same time. Also, fixed effects would not capture firm heterogeneity in case it is time-varying.

We consider transparency and governance quality as two firm-level measures that are plausible candidates as determinants of both institutional ownership and E\&S scores across firms. In Table 7, we perform tests that re-estimate the baseline specifications as in Table 3, but additionally control for a firm's transparency and governance. Transparency is measured by the $\log$ of a firm's transparency score which is defined as the number of data items reported by the company out of all items tracked as part of the ASSET4 scoring system. Our governance measure is based on a firm's level of insider control. To construct this measure we regress the percentage of closely held shares (from Worldscope) on the percentage of institutional ownership of a firm, and retain the residuals from that regression. These residuals are, by construction, orthogonal to institutional ownership, and we refer to them as Insider Control. ${ }^{16}$

\footnotetext{
${ }^{16}$ We prefer this cleaner measure of insider control. All of our results also obtain when we instead use the raw insider control percentages.
} 
Panel A of Table 7 shows that greater E\&S transparency is associated with better E\&S performance, as might be expected. Important from a robustness perspective is the result that the coefficient on Total IO remains positive and significant when controlling for transparency. Relative to our baseline specification in Table 3, explanatory power increases and the coefficient of institutional ownership decreases slightly with the inclusion of transparency. To illustrate, in column 1 where the dependent variable is the overall environmental score, adjusted $\mathrm{R}^{2}$ increases to $64 \%$ (compared to $54 \%$ for the same specification without the transparency control variable in Table 3), while the Total IO coefficient decreases from 0.251 in Table 3 to 0.170 in Table 7, statistical significance remains at the $1 \%$ level.

Panel B repeats this setup, but we now include Insider Control rather than transparency. Insider Control is negatively related to E\&S scores and is significantly different from zero in some of our model specifications. The key result for our purposes is that the coefficient on Total IO is affected very little when we explicitly control for firm-level governance. The negative sign on insider ownership also suggests that, generally speaking, more entrenched insiders do not see investing in E\&S as a private benefit.

In Panel C, where we control for both transparency and insider control, results are essentially unchanged.

\subsection{An alternative measure of environmental and social firm performance}

Finally, we explore whether the positive effect of institutional ownership on environmental and social performance stems from our specific definitions of E\&S measures. One concern is that while ASSET4 provides detailed documentation for its ESG data, and in evaluating firms' E\&S commitments and performance relies predominantly on publicly 
available data, we cannot verify the entire data collection process, or its accuracy. A second concern is that investors have a choice among several providers of ESG data, and there is no standardized framework of capturing such data. While ASSET4 data are widely used in the industry — and among other, available via Datastream feeds - the probability that a specific institutional investor in our sample will rely on a different data provider is significant.

To address both concerns at least partially, we obtain detailed ESG data from Sustainalytics, a competitor of ASSET4. Sustainalytics covers a smaller cross-section of firms and full coverage begins later, in 2009. We match our previous data with all firms in that database, and obtain a sample of firm-years that appear both in ASSET4 and Sustainalytics, which includes 7,259 firm years, or roughly a third of our full sample. We use the Sustainalytics' environmental and social scores. To construct these scores, Sustainalytics looks at similar firm-level information available from annual reports, corporate sustainability reports, NGOs, and news sources, applying their own weighting across items. The correlations between the scores constructed from ASSET4 and Sustainalytics data are neither particularly low nor high, at 0.68 for the environmental performance and 0.52 for social performance.

We use the Sustainalytics data to re-estimate our baseline specifications from Table 3, with the difference being that the dependent variables are now E\&S scores as measured by Sustainalytics. The results, reported in Table 8, show that our main result that lagged institutional investor ownership determines environmental and social performance also obtains with this alternative data source. In terms of economic significance, it is a bit lower than what we find using the ASSET4 database. An interquartile change of total institutional ownership (0.212 for the smaller Sustainalytics sample) is associated with a $2.4 \%$ change in the Sustainalytics environmental score (calculated as $0.212 \times 0.113$ ) and a $1.4 \%$ change in the 
Sustainalytics social score (calculated as $0.212 \times 0.064$ ). Both estimates are significant at the $1 \%$ level.

\section{Conclusion}

As this paper confirms, there is no question that firms around the world are making increasing E\&S commitments. It is difficult, however, to assess the desirability of such commitments from a shareholder perspective. This paper asks whether institutional investors are a driving force behind these firm investments in E\&S initiatives. It is not clear a priori that institutional investors will be a driving force, given challenges of collective action, and potential differences of opinion across investors of the materiality and net benefits of such costly efforts. It is also important to know whether institutional investors are a driving force to help understand whether these investments are likely to improve shareholder welfare. If investors are not behind these changes, stakeholders and entrenched managers with altruistic preferences are the most likely driving forces of such changes. In both cases, they would have an incentive to overinvest in E\&S as they value factors beyond firms' financial returns.

Using a sample of firms and institutional investors across more than 40 countries, we provide new evidence that institutional investors drive firms' E\&S commitments around the world. We find that these investors focus on policies and procedures rather than outputs, and that they have a greater impact on environmental commitments than on social commitments.

We also provide new evidence that the type and geographic domicile of an investor matters. Pension plans, with their longer time horizons, have a greater impact on E\&S commitments than other investors. Hedge funds have a negative impact. Domestic investors 
have a stronger impact than foreign investors, consistent with them having a greater ability to know the levers of change.

Finally, we find that the origin of the foreign investor (the "color of money") matters. If money is all the same, and all are interested only in financial returns, then the country of domicile of the investor should not matter. That the country of domicile does matter, with our finding that U.S. foreign investors have no impact on E\&S scores, while non-U.S. foreign investors do have an impact, suggests societal values have consequences that work through the channel of investments. These results add an additional dimension to the importance of institutional investors. 


\section{References}

Aggarwal, Reena, Isil Erel, Miguel A. Ferreira, and Pedro Matos, 2011, Does governance travel around the world? Evidence from institutional investors, Journal of Financial Economics 100, 154-181.

Casamatta, Catherine, and Sebastien Pouget, 2012, Fund managers' contracts and financial markets' short-termism, Working paper, Toulouse School of Economics.

Cvijanović, Dragana, Amil Dasgupta, and Konstantinos E. Zachariadis, 2015, Ties that bind: How business connections affect mutual fund activism, Journal of Finance, forthcoming.

Cheng, Ing-Haw, Harrison G. Hong, and Kelly Shue, 2015, Do managers do good with other peoples' money? Working paper, Dartmouth College.

Del Guercio, Diane, and Hai Tran, 2012, Institutional investor activism, In: Socially Responsible Finance and Investing: Financial Institutions, Corporations, Investors, and Activists, Eds. H. Kent Baker and John Nofsinger, 359-380, John Wiley \& Sons.

Dimson, Elroy, Oğuzhan Karakaş, and Xi Li, 2015, Active Ownership, Review of Financial Studies, forthcoming.

Ferreira, Miguel A., Massimo Massa, and Pedro Matos, 2010, Shareholders at the gate? Institutional investors and cross border mergers and acquisitions, Review of Financial Studies 23, 601-644.

Ferreira, Miguel A., and Pedro Matos, 2008, The color of investors' money: The role of institutional investors around the world, Journal of Financial Economics 88, 495-533.

Ferrell, Allen, Hao Liang, and Luc Renneboog, 2014, Socially responsible firms, Working Paper, ECGI Working Paper 432/2014.

Franzen, Axel, 2003, Environmental attitudes in international comparison: An analysis of the ISSP surveys 1993 and 2000, Social Science Quarterly 84, 297-308.

Gillan, Stuart, and Laura Starks, 2003, Corporate governance, corporate ownership, and the role of institutional investors: A global perspective, Journal of Applied Finance 13, 422.

Godfrey, Paul, Craig B. Merrill, and Jared M. Hansen, 2009, The relationship between corporate social responsibility and shareholder value: An empirical test of the risk management hypothesis, Strategic Management Journal 30, 425-445.

Gormley, Todd A., and David A. Matsa, 2014, Common errors: How to (and not to) control for unobserved heterogeneity, Review of Financial Studies 27, 617-661. 
Hong, Harrison, and Marcin Kacperczyk, 2009, The price of sin: The effects of social norms on markets, Journal of Financial Economics 93, 15-36.

Hong, Harrison, and Leonard Kostovetsky, 2012, Red and blue investing: Values and finance, Journal of Financial Economics 103, 1-19.

Hong, Harrison, Jeffrey Kubik, and Jose Scheinkman, 2012, Financial constraints on corporate goodness, Working paper, Princeton University.

Hong, Harrison, and Inessa Liskovich, 2015, Crime, punishment and the halo effect of corporate social responsibility, NBER Working Paper 21215.

Iliev, Peter, Karl V. Lins, Darius Miller, and Lukas Roth, 2015, Shareholder voting and corporate governance around the world, Review of Financial Studies 28, 2167-2202.

Ioannou, Ioannis, and George Serafeim, 2015, The Impact of Corporate Social Responsibility on Investment Recommendations: Analysts' Perceptions and Shifting Institutional Logics, Strategic Management Journal (forthcoming).

Leuz, Christian, Karl V. Lins, and Francis E. Warnock, 2009, Do foreigners invest less in poorly governed firms? Review of Financial Studies 22, 3245-3285.

Lins, Karl V., Henri Servaes, and Ane Tamayo, 2015, Social capital, trust, and firm performance during the financial crisis, ECGI Working Paper 446/2015.

Kitzmueller, Markus, and Jay Shimshack, 2012, Economic perspectives on corporate social responsibility, Journal of Economics Literature 50, 51-84.

Margolis, Joshua D., Hillary A. Elfenbein, and James P. Walsh, 2009, Does it pay to be good $\ldots$ and does it matter? A meta-analysis of the relationship between corporate social and financial performance, Working paper, Harvard University.

Servaes, Henri, and Ane Tamayo, 2013, The impact of corporate social responsibility on the value of the firm: the role of customer awareness, Management Science 59, 1045-1061. 
Table 1

Summary Statistics of CSR Scores

This table shows summary statistics of environmental and social scores. Panel A shows numbers for the full sample, and Panel B shows means by industry (using SIC divisions industry groupings) for year 2010. The category scores are calculated as the sum of all indicator variables in one category divided by the number of reported items in that category. The overall category scores are the sum of the individual category scores. Input-based scores are related to a firm's policies and processes in place and the firm's disclosure of such policies and processes. Output-based scores are related to a firm's outputs and actions. Transparency scores are calculated as the number of reported items in a category divided by the number of items a firm could have reported. Appendix B and C describe the indicator variables used to calculate the various environmental and social scores. The ASSET4 $z$-scores are standardized scores, calculated by and obtained from ASSET4 ESG, and measure the environmental and social performance relative to other companies in a given year. The data are from the ASSET4 ESG database and are obtained for the years 2004-2013.

Panel A: Full Sample

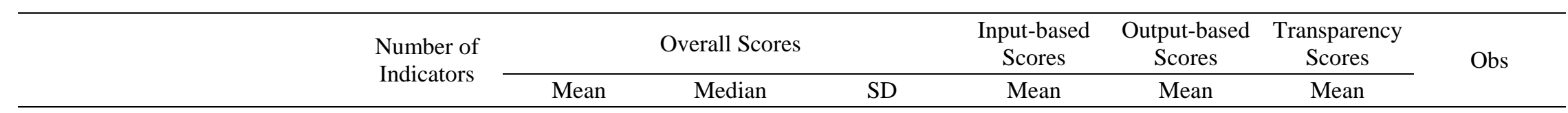

A. Environmental

\begin{tabular}{lllllllll}
\hline 1) Emission Reduction & 28 & 0.39 & 0.36 & 0.21 & 0.27 & 0.96 & 0.79 & 19,849 \\
2) Product Innovation & 25 & 0.28 & 0.17 & 0.23 & 0.26 & 0.32 & 0.76 & 19,849 \\
3) Resource Reduction & 17 & 0.39 & 0.38 & 0.22 & 0.32 & 0.62 & 0.69 & 19,849 \\
\hline Overall Score & 70 & 1.06 & 0.95 & 0.61 & 0.86 & 1.90 & 2.24 & 19,849 \\
\hline
\end{tabular}

B. Social

\begin{tabular}{lllllllll}
\hline 1) Community & 14 & 0.64 & 0.64 & 0.12 & 0.41 & 0.78 & 0.95 & 19,849 \\
2) Diversity and Opportunity & 10 & 0.46 & 0.39 & 0.20 & 0.36 & 0.54 & 0.92 & 19,849 \\
3) Employment Quality & 17 & 0.53 & 0.53 & 0.14 & 0.28 & 0.63 & 0.84 & 19,849 \\
4) Health and Safety & 9 & 0.58 & 0.57 & 0.19 & 0.42 & 0.95 & 0.82 & 19,849 \\
5) Human Rights & 8 & 0.52 & 0.44 & 0.16 & 0.23 & 1.00 & 1.00 & 19,849 \\
6) Product Responsibility & 10 & 0.50 & 0.50 & 0.14 & 0.40 & 0.57 & 1.00 & 19,849 \\
7) Training and Development & 10 & 0.39 & 0.38 & 0.26 & 0.43 & 0.36 & 0.84 & 19,849 \\
\hline Overall Score & 78 & 3.62 & 3.57 & 0.95 & 2.52 & 4.83 & 6.36 \\
\hline C. ASSET4 z-Score & & & & & & & \\
\hline Environmental Score & & 53.65 & 56.21 & 31.55 & & & & \\
Social Score & 52.61 & 54.36 & 31.62 & & & & \\
\end{tabular}


Panel B: Mean Scores by Industry for Year 2010

\begin{tabular}{|c|c|c|c|c|c|c|c|c|c|c|c|}
\hline \multirow[b]{2}{*}{ Scores } & \multirow[b]{2}{*}{$\begin{array}{l}\text { Number of } \\
\text { Indicators }\end{array}$} & \multicolumn{10}{|c|}{ Industries } \\
\hline & & $\begin{array}{l}\text { Agricul- } \\
\text { ture, } \\
\text { Forestry, } \\
\text { Fishing }\end{array}$ & Mining & $\begin{array}{l}\text { Construc- } \\
\text { tion }\end{array}$ & $\begin{array}{l}\text { Manufac- } \\
\text { turing }\end{array}$ & $\begin{array}{l}\text { Transporta- } \\
\text { tion, Public } \\
\text { Utilities }\end{array}$ & $\begin{array}{l}\text { Wholesale } \\
\text { Trade }\end{array}$ & $\begin{array}{l}\text { Retail } \\
\text { Trade }\end{array}$ & $\begin{array}{l}\text { Finance, } \\
\text { Insurance, } \\
\text { Real Estate }\end{array}$ & Services & $\begin{array}{l}\text { Public } \\
\text { Adminis- } \\
\text { tration }\end{array}$ \\
\hline
\end{tabular}

A. Environmental

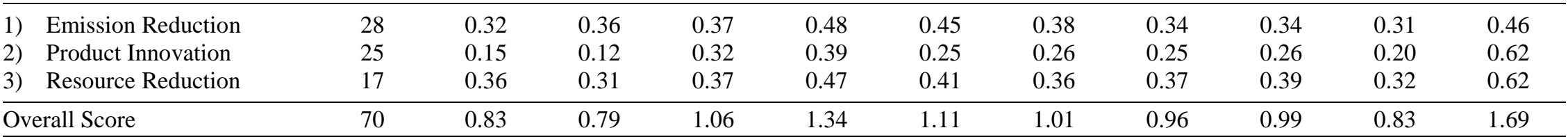

B. Social

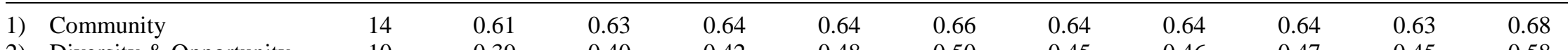

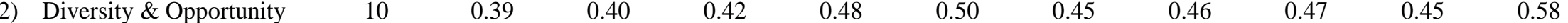

$\begin{array}{llllllllllllll}3) & \text { Employment Quality } & 17 & 0.46 & 0.52 & 0.54 & 0.54 & 0.57 & 0.54 & 0.52 & 0.57 & 0.54 & 0.60\end{array}$

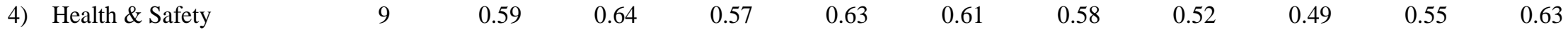

$\begin{array}{lllllllllllll}5) & \text { Human Rights } & 8 & 0.45 & 0.48 & 0.49 & 0.56 & 0.53 & 0.53 & 0.52 & 0.47 & 0.48 & 0.50\end{array}$

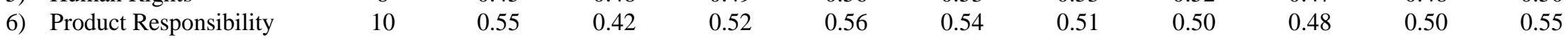

\begin{tabular}{llllllllllll} 
7) Training \& Development & 10 & 0.36 & 0.29 & 0.43 & 0.45 & 0.48 & 0.39 & 0.44 & 0.41 & 0.38 & 0.63 \\
\hline Overall Score & 78 & 3.41 & 3.37 & 3.60 & 3.86 & 3.88 & 3.64 & 3.60 & 3.54 & 3.54 & 4.17 \\
\hline
\end{tabular}

\section{ASSET4 $z$-Score}

\begin{tabular}{|c|c|c|c|c|c|c|c|c|c|c|}
\hline Environmental Score & 40.46 & 36.84 & 51.99 & 65.26 & 55.08 & 48.50 & 45.82 & 45.37 & 39.93 & 88.75 \\
\hline Social Score & 44.06 & 39.44 & 48.68 & 58.32 & 57.60 & 50.88 & 48.35 & 46.18 & 45.60 & 74.59 \\
\hline
\end{tabular}


Table 2

Summary Statistics by Country

This table shows means of environmental and social scores and institutional ownership by country. The data are from the ASSET4 ESG database and Factset, and they are obtained for the years 2004-2013. Appendix B and C describe the indicator variables used to calculate the various environmental and social scores.

\begin{tabular}{|c|c|c|c|c|c|c|c|}
\hline \multirow{2}{*}{ Country } & \multicolumn{2}{|c|}{ Overall Scores } & \multirow{2}{*}{$\begin{array}{c}\text { Institutional } \\
\text { Ownership (\%) }\end{array}$} & \multirow{2}{*}{$\begin{array}{c}\text { Coverage } \\
\text { Start }\end{array}$} & \multirow{2}{*}{$\begin{array}{c}\text { Obs } \\
(2010)\end{array}$} & \multirow{2}{*}{$\begin{array}{l}\text { Firms } \\
\text { (Total) }\end{array}$} & \multirow{2}{*}{$\begin{array}{c}\text { Obs } \\
\text { (Total) }\end{array}$} \\
\hline & Environment & Social & & & & & \\
\hline Australia & 0.79 & 3.28 & 10.8 & 2004 & 267 & 385 & 1,739 \\
\hline Austria & 1.21 & 4.01 & 18.4 & 2004 & 16 & 18 & 147 \\
\hline Belgium & 1.18 & 3.61 & 16.4 & 2004 & 28 & 29 & 237 \\
\hline Brazil & 1.08 & 4.08 & 22.5 & 2004 & 75 & 88 & 342 \\
\hline Canada & 0.83 & 3.36 & 42.0 & 2004 & 254 & 309 & 1,807 \\
\hline Chile & 0.84 & 3.40 & 6.1 & 2007 & 17 & 19 & 83 \\
\hline China & 0.64 & 2.92 & 14.3 & 2004 & 109 & 126 & 514 \\
\hline Colombia & 0.76 & 3.15 & 4.1 & 2009 & 9 & 12 & 37 \\
\hline Denmark & 1.29 & 4.03 & 22.9 & 2004 & 24 & 27 & 225 \\
\hline Egypt & 0.51 & 3.12 & 8.4 & 2008 & 10 & 11 & 36 \\
\hline Finland & 1.57 & 4.23 & 31.4 & 2004 & 26 & 27 & 230 \\
\hline France & 1.60 & 4.55 & 25.6 & 2004 & 92 & 99 & 820 \\
\hline Germany & 1.48 & 4.40 & 27.9 & 2004 & 78 & 90 & 694 \\
\hline Greece & 1.09 & 3.70 & 13.2 & 2004 & 20 & 24 & 192 \\
\hline Hong Kong & 0.73 & 3.15 & 16.7 & 2004 & 102 & 119 & 728 \\
\hline India & 1.11 & 3.89 & 15.8 & 2007 & 58 & 88 & 347 \\
\hline Indonesia & 0.91 & 3.80 & 10.9 & 2008 & 24 & 29 & 108 \\
\hline Ireland & 1.07 & 3.38 & 39.6 & 2004 & 16 & 20 & 152 \\
\hline Israel & 0.89 & 3.46 & 24.7 & 2004 & 15 & 16 & 68 \\
\hline Italy & 1.22 & 4.27 & 14.4 & 2004 & 46 & 57 & 437 \\
\hline Japan & 1.34 & 3.62 & 13.5 & 2004 & 389 & 417 & 3,594 \\
\hline Luxembourg & 1.28 & 3.92 & 35.6 & 2004 & 6 & 9 & 59 \\
\hline Malaysia & 0.79 & 3.50 & 8.1 & 2008 & 41 & 45 & 178 \\
\hline Mexico & 0.96 & 3.64 & 18.6 & 2007 & 21 & 29 & 118 \\
\hline Netherlands & 1.41 & 4.32 & 35.7 & 2004 & 32 & 49 & 319 \\
\hline New Zealand & 1.04 & 3.59 & 14.0 & 2004 & 10 & 13 & 94 \\
\hline Norway & 1.35 & 4.30 & 35.6 & 2004 & 15 & 19 & 165 \\
\hline Philippines & 0.82 & 3.44 & 12.6 & 2008 & 18 & 23 & 76 \\
\hline Poland & 0.78 & 3.32 & 30.5 & 2007 & 20 & 24 & 88 \\
\hline Portugal & 1.45 & 4.59 & 10.6 & 2004 & 13 & 13 & 104 \\
\hline Russia & 0.86 & 3.65 & 14.4 & 2004 & 29 & 31 & 158 \\
\hline Singapore & 0.84 & 3.40 & 19.3 & 2004 & 42 & 47 & 365 \\
\hline South Africa & 1.23 & 4.39 & 21.4 & 2008 & 44 & 127 & 372 \\
\hline South Korea & 1.25 & 3.64 & 11.6 & 2004 & 93 & 105 & 411 \\
\hline Spain & 1.56 & 4.66 & 13.4 & 2004 & 42 & 55 & 413 \\
\hline Sweden & 1.49 & 4.19 & 39.4 & 2004 & 47 & 53 & 459 \\
\hline Switzerland & 1.15 & 3.79 & 26.8 & 2004 & 63 & 72 & 524 \\
\hline Taiwan & 0.90 & 3.08 & 14.7 & 2004 & 123 & 134 & 460 \\
\hline Thailand & 0.98 & 3.74 & 13.6 & 2007 & 20 & 29 & 103 \\
\hline Turkey & 1.04 & 3.81 & 14.0 & 2008 & 22 & 25 & 111 \\
\hline U.K. & 1.24 & 4.11 & 34.3 & 2004 & 285 & 365 & 2,735 \\
\hline Total & 1.09 & 3.69 & 21.4 & & 2,661 & 3,277 & 19,849 \\
\hline
\end{tabular}




\section{Figure 1}

Environmental and Social Scores and Institutional Investors' Ownership over Time

These figures show means of environmental and social scores and institutional ownership by year. The data are from the ASSET4 ESG database and Factset and are obtained for the years 2004-2013. Appendix B and C describe the indicator variables used to calculate the various environmental and social scores.

Panel A: Constant Panel 2004-2013 (805 Firms)
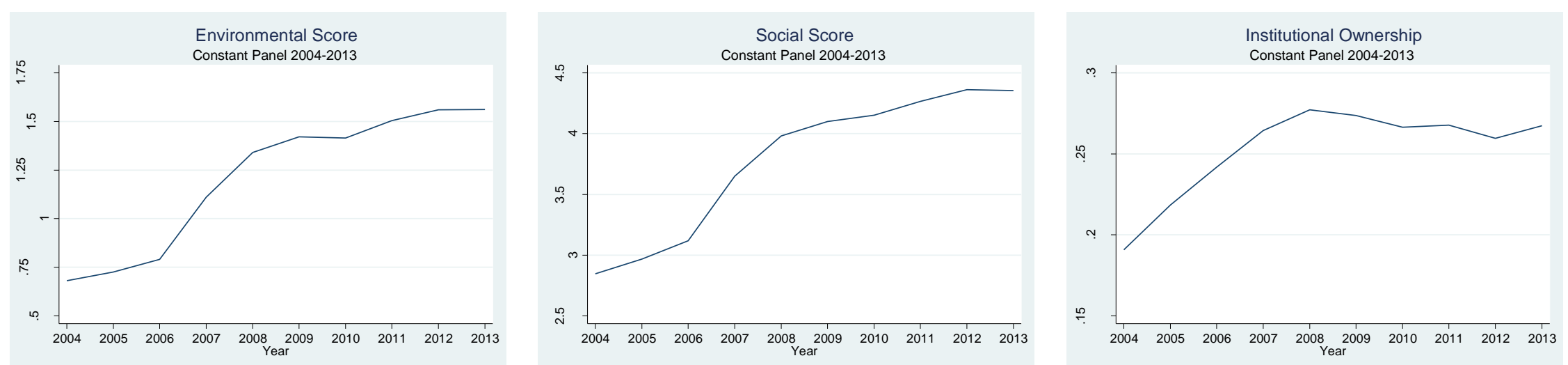

Panel B: Constant Panel 2009-2013 (1,662 Firms)
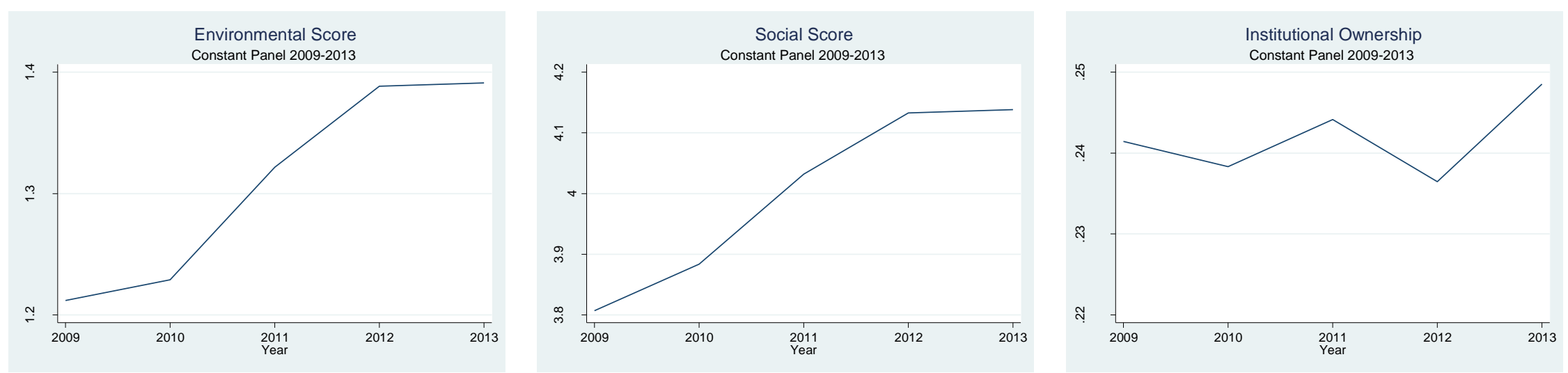
Panel C: Overall Scores, Input-based and Output-based Scores
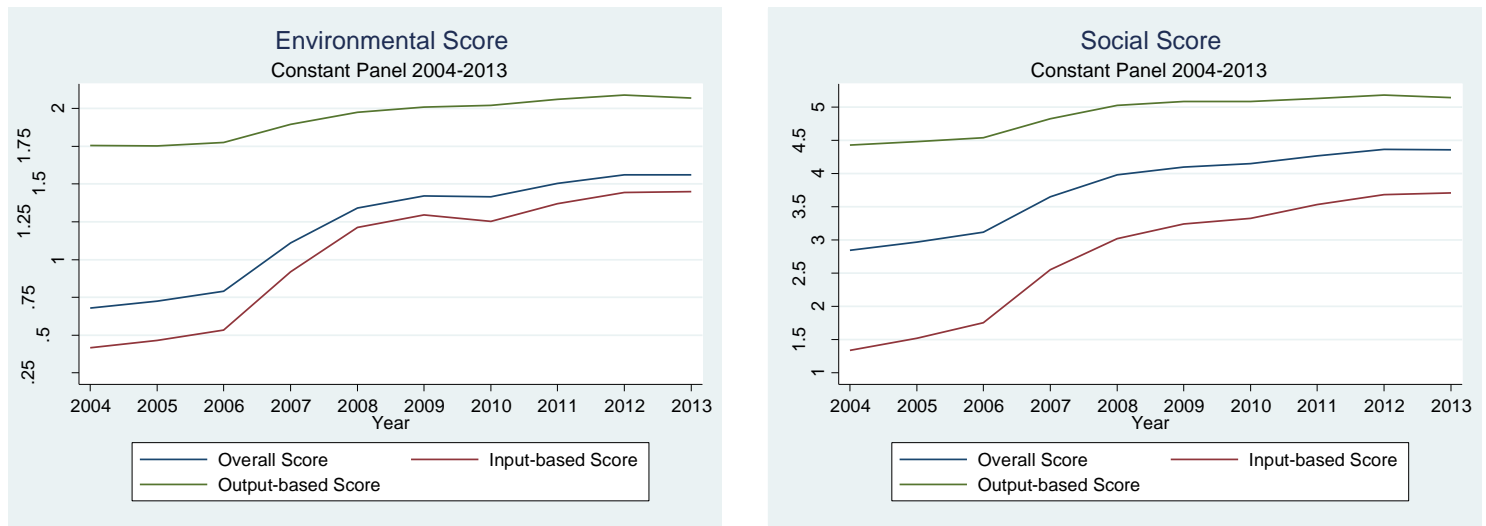

Constant Panel 2004-2013 (805 Firms)
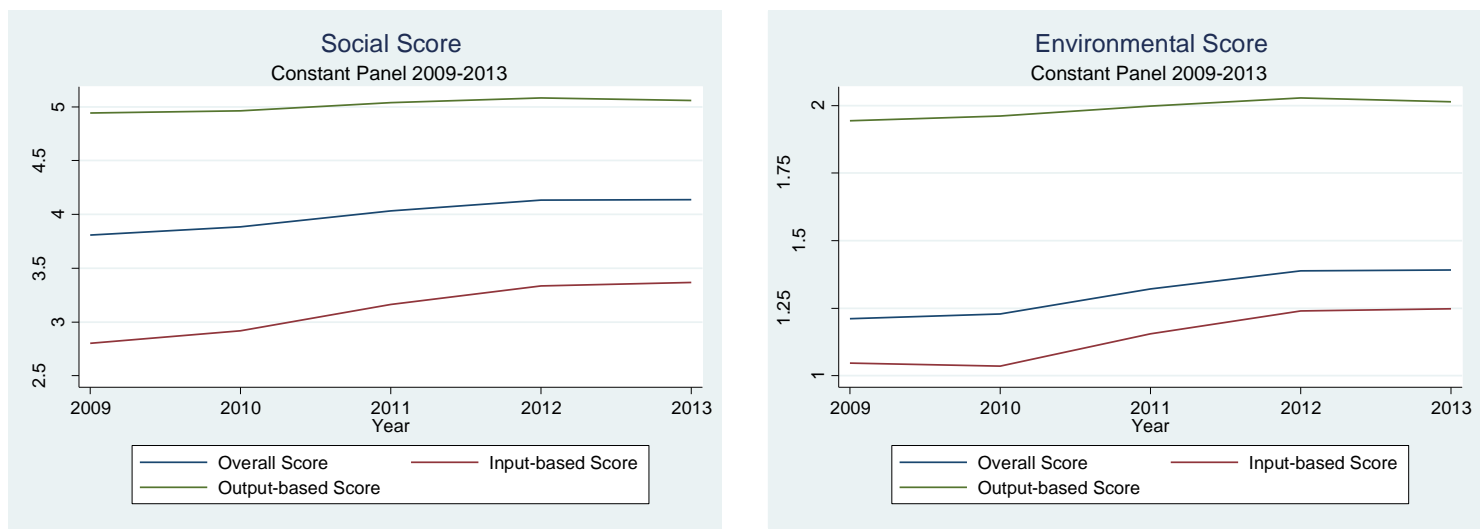

Constant Panel 2009-2013 (1,662 Firms) 
Table 3

Environmental and Social Scores and Institutional Investors

This table reports regression estimates of environmental and social scores on institutional ownership and control variables. In Panel A, the dependent variables are the natural logarithm of the overall environmental score (column 1), the natural logarithm of the ASSET4 environmental $z$-score (column 2), the natural logarithm of the overall environmental input-based and output-based scores (columns $3 \& 4$ ), and the natural logarithm of the category scores (column 5-7). In Panel B, the dependent variables are the natural logarithm of the overall social score (column 1), the natural logarithm of the ASSET4 social $z$-score (column 2), the natural logarithm of overall social input-based and output-based scores (columns $3 \& 4$ ), and the natural logarithm of the category scores (column 5-11) Panel C and D report results for subsamples. The below-median subsample contains firms that have environmental/social scores below the sample median at the time they enter the sample. The above-median subsample contains firms that have environmental/social scores above (or equal to) the sample median at the time they enter the sample. A fully-interacted model is used to test for differences in coefficients between the subsamples. The data are from the ASSET4 ESG database, Factset, and Worldscope, and they are obtained for the years 2004-2013. Appendix B and C describe the indicator variables used to calculate the various environmental and social scores. We winsorize all variables at the 1st and 99th percentiles. All right-hand side variables are lagged by one year. Standard errors are clustered at the country-level and $p$-values are reported in parentheses.

Panel A: Environmental Scores

\begin{tabular}{|c|c|c|c|c|c|c|c|}
\hline & \multirow[b]{2}{*}{$\begin{array}{l}\text { Overall } \\
\text { Score }\end{array}$} & \multirow[b]{2}{*}{$\begin{array}{c}\text { ASSET4 } \\
z \text {-Score }\end{array}$} & \multirow[b]{2}{*}{$\begin{array}{c}\text { Input-based } \\
\text { Score }\end{array}$} & \multirow[b]{2}{*}{$\begin{array}{c}\text { Output-based } \\
\text { Score }\end{array}$} & \multicolumn{3}{|c|}{ Category Scores } \\
\hline & & & & & $\begin{array}{l}\text { Emission } \\
\text { Reduction }\end{array}$ & $\begin{array}{c}\text { Product } \\
\text { Innovation }\end{array}$ & $\begin{array}{l}\text { Resource } \\
\text { Reduction }\end{array}$ \\
\hline & $(1)$ & $(2)$ & $(3)$ & $(4)$ & $(5)$ & $(6)$ & $(7)$ \\
\hline \multirow[t]{2}{*}{ Total $\mathrm{IO}_{\mathrm{t}-1}$} & 0.251 & 0.357 & 0.539 & 0.001 & 0.174 & 0.112 & 0.221 \\
\hline & $(0.00)$ & $(0.00)$ & $(0.00)$ & $(0.94)$ & $(0.00)$ & $(0.03)$ & $(0.00)$ \\
\hline \multirow{2}{*}{ Log (Total Assets) $)_{t-1}$} & 0.213 & 0.251 & 0.408 & 0.019 & 0.148 & 0.170 & 0.167 \\
\hline & $(0.00)$ & $(0.00)$ & $(0.00)$ & $(0.00)$ & $(0.00)$ & $(0.00)$ & $(0.00)$ \\
\hline \multirow[t]{2}{*}{ Tangibility $_{\mathrm{t}-1}$} & 0.193 & 0.225 & 0.444 & -0.007 & 0.169 & 0.034 & 0.168 \\
\hline & $(0.00)$ & $(0.00)$ & $(0.00)$ & $(0.38)$ & $(0.00)$ & $(0.52)$ & $(0.00)$ \\
\hline \multirow[t]{2}{*}{ Leverage $_{t-1}$} & -0.114 & -0.135 & -0.205 & -0.010 & -0.094 & -0.094 & -0.085 \\
\hline & $(0.14)$ & $(0.23)$ & $(0.13)$ & $(0.36)$ & $(0.04)$ & $(0.33)$ & $(0.12)$ \\
\hline \multirow[t]{2}{*}{ Tobin's $\mathrm{q}_{\mathrm{t}-1}$} & 0.032 & 0.025 & 0.034 & 0.009 & 0.020 & 0.040 & 0.026 \\
\hline & $(0.00)$ & $(0.01)$ & $(0.03)$ & $(0.00)$ & $(0.00)$ & $(0.00)$ & $(0.00)$ \\
\hline \multirow[t]{2}{*}{$\mathrm{ROA}_{\mathrm{t}-1}$} & 0.088 & 0.193 & 0.242 & -0.042 & 0.098 & -0.184 & 0.122 \\
\hline & $(0.39)$ & $(0.14)$ & $(0.39)$ & $(0.00)$ & $(0.10)$ & $(0.04)$ & $(0.13)$ \\
\hline Country Fixed Effects & Yes & Yes & Yes & Yes & Yes & Yes & Yes \\
\hline Year Fixed Effects & Yes & Yes & Yes & Yes & Yes & Yes & Yes \\
\hline Industry Fixed Effects & Yes & Yes & Yes & Yes & Yes & Yes & Yes \\
\hline Adjusted $R^{2}$ & 0.543 & 0.445 & 0.474 & 0.355 & 0.534 & 0.475 & 0.474 \\
\hline Obs & 19,849 & 19,785 & 19,849 & 19,849 & 19,849 & 19,849 & 19,849 \\
\hline
\end{tabular}


Panel B: Social Scores

\begin{tabular}{|c|c|c|c|c|c|c|c|c|c|c|c|}
\hline & \multirow[b]{2}{*}{$\begin{array}{l}\text { Overall } \\
\text { Score }\end{array}$} & \multirow[b]{2}{*}{$\begin{array}{l}\text { ASSET4 } \\
z-\text { Score }\end{array}$} & \multirow[b]{2}{*}{$\begin{array}{l}\text { Input- } \\
\text { based } \\
\text { Score }\end{array}$} & \multirow[b]{2}{*}{$\begin{array}{l}\text { Output- } \\
\text { based } \\
\text { Score }\end{array}$} & \multicolumn{7}{|c|}{ Category Scores } \\
\hline & & & & & Community & $\begin{array}{l}\text { Diversity \& } \\
\text { Opportunity }\end{array}$ & $\begin{array}{c}\text { Employ- } \\
\text { ment } \\
\text { Quality }\end{array}$ & $\begin{array}{l}\text { Health \& } \\
\text { Safety }\end{array}$ & $\begin{array}{l}\text { Human } \\
\text { Rights }\end{array}$ & $\begin{array}{c}\text { Product } \\
\text { Responsibi- } \\
\text { lity }\end{array}$ & $\begin{array}{c}\text { Training \& } \\
\text { Develop- } \\
\text { ment }\end{array}$ \\
\hline & $(1)$ & $(2)$ & $(3)$ & (4) & $(5)$ & $(6)$ & $(7)$ & $(8)$ & $(9)$ & $(10)$ & $(11)$ \\
\hline \multirow{2}{*}{ Total $\mathrm{IO}_{\mathrm{t}-1}$} & 0.126 & 0.466 & 0.405 & 0.015 & 0.043 & 0.079 & 0.055 & 0.068 & 0.080 & 0.072 & 0.285 \\
\hline & $(0.00)$ & $(0.00)$ & $(0.00)$ & $(0.02)$ & $(0.01)$ & $(0.00)$ & $(0.00)$ & $(0.00)$ & $(0.00)$ & $(0.00)$ & $(0.00)$ \\
\hline \multirow{2}{*}{$\log (\text { Total Assets })_{t-1}$} & 0.084 & 0.272 & 0.223 & 0.014 & 0.030 & 0.080 & 0.024 & 0.056 & 0.053 & 0.032 & 0.189 \\
\hline & $(0.00)$ & $(0.00)$ & $(0.00)$ & $(0.00)$ & $(0.00)$ & $(0.00)$ & $(0.00)$ & $(0.00)$ & $(0.00)$ & $(0.00)$ & $(0.00)$ \\
\hline \multirow[t]{2}{*}{ Tangibility $\mathrm{t}-1$} & 0.032 & 0.114 & 0.139 & -0.001 & 0.012 & 0.027 & 0.004 & 0.054 & 0.001 & 0.011 & 0.051 \\
\hline & $(0.17)$ & $(0.17)$ & $(0.05)$ & $(0.83)$ & $(0.11)$ & $(0.10)$ & $(0.83)$ & $(0.00)$ & $(0.97)$ & $(0.38)$ & $(0.56)$ \\
\hline \multirow[t]{2}{*}{ Leverage $_{t-1}$} & -0.041 & -0.129 & -0.085 & -0.007 & -0.024 & -0.020 & -0.019 & -0.024 & -0.017 & -0.013 & -0.115 \\
\hline & $(0.14)$ & $(0.24)$ & $(0.18)$ & $(0.31)$ & $(0.01)$ & $(0.60)$ & $(0.06)$ & $(0.41)$ & $(0.38)$ & $(0.34)$ & $(0.12)$ \\
\hline \multirow[t]{2}{*}{ Tobin's q $\mathrm{t}-1$} & 0.015 & 0.030 & 0.039 & 0.003 & 0.003 & 0.019 & 0.010 & 0.003 & 0.015 & 0.006 & 0.022 \\
\hline & $(0.00)$ & $(0.04)$ & $(0.00)$ & $(0.00)$ & $(0.05)$ & $(0.00)$ & $(0.00)$ & $(0.35)$ & $(0.00)$ & $(0.00)$ & $(0.04)$ \\
\hline \multirow[t]{2}{*}{$\operatorname{ROA}_{t-1}$} & 0.067 & 0.359 & 0.157 & 0.006 & -0.018 & 0.022 & 0.063 & 0.065 & -0.022 & 0.035 & 0.405 \\
\hline & $(0.11)$ & $(0.04)$ & $(0.20)$ & $(0.52)$ & $(0.40)$ & $(0.61)$ & $(0.01)$ & $(0.05)$ & $(0.35)$ & $(0.19)$ & $(0.00)$ \\
\hline Country Fixed Effects & Yes & Yes & Yes & Yes & Yes & Yes & Yes & Yes & Yes & Yes & Yes \\
\hline Year Fixed Effects & Yes & Yes & Yes & Yes & Yes & Yes & Yes & Yes & Yes & Yes & Yes \\
\hline Industry Fixed Effects & Yes & Yes & Yes & Yes & Yes & Yes & Yes & Yes & Yes & Yes & Yes \\
\hline Adjusted $R^{2}$ & 0.523 & 0.393 & 0.446 & 0.369 & 0.345 & 0.418 & 0.356 & 0.438 & 0.435 & 0.396 & 0.413 \\
\hline Obs & 19,849 & 19,785 & 19,849 & 19,849 & 19,849 & 19,849 & 19,849 & 19,849 & 19,849 & 19,849 & 19,849 \\
\hline
\end{tabular}


Panel C: Splits by Below/Above Median Environmental Score

\begin{tabular}{|c|c|c|c|c|c|c|c|c|}
\hline & \multicolumn{4}{|c|}{ Below Median Environmental Scores } & \multicolumn{4}{|c|}{ Above Median Environmental Scores } \\
\hline & $\begin{array}{c}\text { Overall } \\
\text { Score }\end{array}$ & $\begin{array}{c}\text { ASSET4 } \\
z \text {-Score }\end{array}$ & $\begin{array}{c}\text { Input-based } \\
\text { Score }\end{array}$ & $\begin{array}{c}\text { Output-based } \\
\text { Score }\end{array}$ & $\begin{array}{l}\text { Overall } \\
\text { Score }\end{array}$ & $\begin{array}{c}\text { ASSET4 } \\
z \text {-Score }\end{array}$ & $\begin{array}{c}\text { Input-based } \\
\text { Score }\end{array}$ & $\begin{array}{c}\text { Output-based } \\
\text { Score }\end{array}$ \\
\hline & (1) & $(2)$ & (3) & (4) & $(5)$ & (6) & $(7)$ & $(8)$ \\
\hline \multirow[t]{2}{*}{ Total $\mathrm{IO}_{\mathrm{t}-1}$} & 0.243 & 0.382 & 0.570 & 0.002 & 0.149 & 0.195 & 0.218 & 0.016 \\
\hline & $(0.01)$ & $(0.00)$ & $(0.03)$ & $(0.92)$ & $(0.01)$ & $(0.02)$ & $(0.03)$ & $(0.08)$ \\
\hline \multirow[t]{2}{*}{ Log (Total Assets) ${ }_{t-1}$} & 0.180 & 0.248 & 0.393 & 0.009 & 0.107 & 0.071 & 0.155 & 0.021 \\
\hline & $(0.00)$ & $(0.00)$ & $(0.00)$ & $(0.00)$ & $(0.00)$ & $(0.00)$ & $(0.00)$ & $(0.00)$ \\
\hline \multirow[t]{2}{*}{ Tangibility $\mathrm{t}-1$} & 0.145 & 0.191 & 0.365 & -0.011 & 0.012 & -0.037 & 0.060 & 0.008 \\
\hline & $(0.00)$ & $(0.01)$ & $(0.00)$ & $(0.19)$ & $(0.79)$ & $(0.51)$ & $(0.39)$ & $(0.28)$ \\
\hline \multirow[t]{2}{*}{ Leverage $_{\mathrm{t}-1}$} & -0.140 & -0.209 & -0.327 & -0.009 & -0.129 & -0.025 & -0.154 & -0.013 \\
\hline & $(0.08)$ & $(0.03)$ & $(0.02)$ & $(0.44)$ & $(0.01)$ & $(0.63)$ & $(0.03)$ & $(0.26)$ \\
\hline \multirow{2}{*}{ Tobin's q $\mathrm{t}-1$} & 0.029 & 0.036 & 0.056 & 0.005 & 0.018 & 0.014 & 0.018 & 0.007 \\
\hline & $(0.00)$ & $(0.00)$ & $(0.01)$ & $(0.00)$ & $(0.05)$ & $(0.12)$ & $(0.15)$ & $(0.00)$ \\
\hline \multirow{2}{*}{$\mathrm{ROA}_{\mathrm{t}-1}$} & 0.144 & 0.204 & 0.211 & -0.036 & -0.030 & 0.004 & -0.019 & -0.002 \\
\hline & $(0.18)$ & $(0.18)$ & $(0.52)$ & $(0.00)$ & $(0.81)$ & $(0.98)$ & $(0.93)$ & $(0.91)$ \\
\hline Country Fixed Effects & Yes & Yes & Yes & Yes & Yes & Yes & Yes & Yes \\
\hline Industry Fixed Effects & Yes & Yes & Yes & Yes & Yes & Yes & Yes & Yes \\
\hline Year Fixed Effects & Yes & Yes & Yes & Yes & Yes & Yes & Yes & Yes \\
\hline Adjusted $R^{2}$ & 0.446 & 0.329 & 0.423 & 0.319 & 0.611 & 0.228 & 0.536 & 0.344 \\
\hline Obs & 11,918 & 11,907 & 11,752 & 10,564 & 7,931 & 7,878 & 8,097 & 9,285 \\
\hline $\begin{array}{l}p \text {-value of Difference of } \\
\text { coefficients on Total IO } \\
\text { for Below/Above Median } \\
\text { Subsamples }\end{array}$ & $(0.05)$ & $(0.05)$ & $(0.06)$ & $(0.70)$ & & & & \\
\hline
\end{tabular}


Panel D: Splits by Below/Above Median Social Score

\begin{tabular}{|c|c|c|c|c|c|c|c|c|}
\hline & \multicolumn{4}{|c|}{ Below Median Social Scores } & \multicolumn{4}{|c|}{ Above Median Social Scores } \\
\hline & $\begin{array}{c}\text { Overall } \\
\text { Score }\end{array}$ & $\begin{array}{c}\text { ASSET4 } \\
z \text {-Score }\end{array}$ & $\begin{array}{c}\text { Input-based } \\
\text { Score }\end{array}$ & $\begin{array}{c}\text { Output-based } \\
\text { Score }\end{array}$ & $\begin{array}{l}\text { Overall } \\
\text { Score }\end{array}$ & $\begin{array}{c}\text { ASSET4 } \\
z \text {-Score }\end{array}$ & $\begin{array}{c}\text { Input-based } \\
\text { Score }\end{array}$ & $\begin{array}{c}\text { Output-based } \\
\text { Score }\end{array}$ \\
\hline & (1) & $(2)$ & (3) & (4) & (5) & (6) & (7) & $(8)$ \\
\hline \multirow[t]{2}{*}{ Total $\mathrm{IO}_{\mathrm{t}-1}$} & 0.130 & 0.507 & 0.488 & 0.023 & 0.039 & 0.064 & 0.070 & -0.009 \\
\hline & $(0.00)$ & $(0.00)$ & $(0.00)$ & $(0.00)$ & $(0.11)$ & $(0.41)$ & $(0.22)$ & $(0.30)$ \\
\hline \multirow[t]{2}{*}{ Log (Total Assets) ${ }_{t-1}$} & 0.071 & 0.275 & 0.203 & 0.013 & 0.040 & 0.078 & 0.085 & 0.007 \\
\hline & $(0.00)$ & $(0.00)$ & $(0.00)$ & $(0.00)$ & $(0.00)$ & $(0.00)$ & $(0.00)$ & $(0.00)$ \\
\hline \multirow[t]{2}{*}{ Tangibility $\mathrm{t}-1$} & -0.004 & 0.032 & 0.010 & -0.007 & 0.004 & 0.008 & -0.012 & 0.005 \\
\hline & $(0.89)$ & $(0.77)$ & $(0.89)$ & $(0.27)$ & $(0.76)$ & $(0.84)$ & $(0.62)$ & $(0.38)$ \\
\hline \multirow[t]{2}{*}{ Leverage $_{\mathrm{t}-1}$} & -0.027 & -0.151 & -0.011 & -0.000 & -0.033 & -0.057 & -0.066 & -0.012 \\
\hline & $(0.55)$ & $(0.41)$ & $(0.91)$ & $(0.96)$ & $(0.22)$ & $(0.28)$ & $(0.17)$ & $(0.06)$ \\
\hline \multirow[t]{2}{*}{ Tobin's q $\mathrm{t}-1$} & 0.014 & 0.042 & 0.042 & 0.003 & 0.010 & 0.016 & 0.022 & 0.003 \\
\hline & $(0.01)$ & $(0.05)$ & $(0.01)$ & $(0.00)$ & $(0.01)$ & $(0.14)$ & $(0.02)$ & $(0.01)$ \\
\hline \multirow{2}{*}{$\mathrm{ROA}_{\mathrm{t}-1}$} & 0.053 & 0.329 & 0.119 & 0.003 & 0.128 & 0.196 & 0.092 & 0.025 \\
\hline & $(0.26)$ & $(0.10)$ & $(0.40)$ & $(0.78)$ & $(0.00)$ & $(0.08)$ & $(0.19)$ & $(0.08)$ \\
\hline Country Fixed Effects & Yes & Yes & Yes & Yes & Yes & Yes & Yes & Yes \\
\hline Industry Fixed Effects & Yes & Yes & Yes & Yes & Yes & Yes & Yes & Yes \\
\hline Year Fixed Effects & Yes & Yes & Yes & Yes & Yes & Yes & Yes & Yes \\
\hline Adjusted $R^{2}$ & 0.456 & 0.293 & 0.446 & 0.341 & 0.65 & 0.275 & 0.629 & 0.376 \\
\hline Obs & 11,989 & 11,862 & 11,858 & 11,410 & 7,860 & 7,923 & 7,991 & 8,439 \\
\hline $\begin{array}{l}p \text {-value of Difference of } \\
\text { coefficients on Total IO } \\
\text { for Below/Above Median } \\
\text { Subsamples }\end{array}$ & $(0.00)$ & $(0.00)$ & $(0.00)$ & $(0.00)$ & & & & \\
\hline
\end{tabular}


Table 4

Environmental and Social Scores and Institutional Investors: Firm Fixed Effects Regressions

This table reports firm fixed effects regression estimates of environmental and social scores on institutional ownership and control variables. The dependent variables are the natural logarithm of environmental and social scores. The data are from the ASSET4 ESG database, Factset, and Worldscope, and they are obtained for the years 2004-2013. Appendix B and C describe the indicator variables used to calculate the various environmental and social scores. We winsorize all variables at the 1st and 99th percentiles. All right-hand side variables are lagged by one year. Standard errors are clustered at the country-level and $p$-values are reported in parentheses.

\begin{tabular}{|c|c|c|c|c|c|c|c|c|}
\hline & \multicolumn{4}{|c|}{ Environmental Scores } & \multicolumn{4}{|c|}{ Social Scores } \\
\hline & $\begin{array}{l}\text { Overall } \\
\text { Score }\end{array}$ & $\begin{array}{l}\text { ASSET4 } \\
z \text {-Score }\end{array}$ & $\begin{array}{c}\text { Input-based } \\
\text { Score }\end{array}$ & $\begin{array}{l}\text { Output-based } \\
\text { Score }\end{array}$ & $\begin{array}{l}\text { Overall } \\
\text { Score }\end{array}$ & $\begin{array}{l}\text { ASSET4 } \\
z \text {-Score }\end{array}$ & $\begin{array}{c}\text { Input-based } \\
\text { Score }\end{array}$ & $\begin{array}{c}\text { Output-based } \\
\text { Score }\end{array}$ \\
\hline & $(1)$ & $(2)$ & $(3)$ & $(4)$ & $(5)$ & $(6)$ & $(7)$ & $(8)$ \\
\hline Total $\mathrm{IO}_{\mathrm{t}-1}$ & $\begin{array}{l}0.121 \\
(0.00)\end{array}$ & $\begin{array}{l}0.163 \\
(0.01)\end{array}$ & $\begin{array}{l}0.291 \\
(0.00)\end{array}$ & $\begin{array}{l}0.007 \\
(0.34)\end{array}$ & $\begin{array}{l}0.046 \\
(0.05)\end{array}$ & $\begin{array}{l}0.194 \\
(0.05)\end{array}$ & $\begin{array}{l}0.173 \\
(0.14)\end{array}$ & $\begin{array}{l}0.010 \\
(0.05)\end{array}$ \\
\hline Log $(\text { Total Assets })_{t-1}$ & $\begin{array}{l}0.071 \\
(0.00)\end{array}$ & $\begin{array}{l}0.110 \\
(0.00)\end{array}$ & $\begin{array}{l}0.226 \\
(0.00)\end{array}$ & $\begin{array}{l}-0.005 \\
(0.09)\end{array}$ & $\begin{array}{l}0.024 \\
(0.00)\end{array}$ & $\begin{array}{l}0.105 \\
(0.00)\end{array}$ & $\begin{array}{l}0.095 \\
(0.00)\end{array}$ & $\begin{array}{l}0.003 \\
(0.11)\end{array}$ \\
\hline Tangibility $\mathrm{t}-1$ & $\begin{array}{c}-0.063 \\
(0.14)\end{array}$ & $\begin{array}{c}-0.091 \\
(0.08)\end{array}$ & $\begin{array}{c}-0.052 \\
(0.59)\end{array}$ & $\begin{array}{c}-0.005 \\
(0.71)\end{array}$ & $\begin{array}{c}-0.037 \\
(0.09)\end{array}$ & $\begin{array}{c}-0.046 \\
(0.43)\end{array}$ & $\begin{array}{l}0.025 \\
(0.71)\end{array}$ & $\begin{array}{c}-0.017 \\
(0.00)\end{array}$ \\
\hline Leverage $_{t-1}$ & $\begin{array}{c}-0.028 \\
(0.43)\end{array}$ & $\begin{array}{c}-0.050 \\
(0.33)\end{array}$ & $\begin{array}{c}-0.028 \\
(0.75)\end{array}$ & $\begin{array}{c}-0.004 \\
(0.64)\end{array}$ & $\begin{array}{l}0.001 \\
(0.95)\end{array}$ & $\begin{array}{c}-0.082 \\
(0.30)\end{array}$ & $\begin{array}{l}0.011 \\
(0.91)\end{array}$ & $\begin{array}{r}-0.005 \\
(0.27)\end{array}$ \\
\hline Tobin's $\mathrm{q}_{\mathrm{t}-1}$ & $\begin{array}{l}0.014 \\
(0.02)\end{array}$ & $\begin{array}{l}0.017 \\
(0.03)\end{array}$ & $\begin{array}{l}0.016 \\
(0.15)\end{array}$ & $\begin{array}{l}0.003 \\
(0.01)\end{array}$ & $\begin{array}{l}0.004 \\
(0.05)\end{array}$ & $\begin{array}{l}0.002 \\
(0.72)\end{array}$ & $\begin{array}{c}-0.011 \\
(0.37)\end{array}$ & $\begin{array}{l}0.001 \\
(0.00)\end{array}$ \\
\hline $\mathrm{ROA}_{\mathrm{t}-1}$ & $\begin{array}{r}-0.004 \\
(0.93) \\
\end{array}$ & $\begin{array}{c}-0.040 \\
(0.51)\end{array}$ & $\begin{array}{l}-0.045 \\
(0.71)\end{array}$ & $\begin{array}{l}0.011 \\
(0.08)\end{array}$ & $\begin{array}{l}0.031 \\
(0.01)\end{array}$ & $\begin{array}{l}0.127 \\
(0.02)\end{array}$ & $\begin{array}{l}0.124 \\
(0.03)\end{array}$ & $\begin{array}{l}0.002 \\
(0.69)\end{array}$ \\
\hline Firm Fixed Effects & Yes & Yes & Yes & Yes & Yes & Yes & Yes & Yes \\
\hline Year Fixed Effects & Yes & Yes & Yes & Yes & Yes & Yes & Yes & Yes \\
\hline Adjusted $R^{2}$ & 0.639 & 0.109 & 0.526 & 0.290 & 0.685 & 0.115 & 0.569 & 0.419 \\
\hline Obs & 19,849 & 19,785 & 19,849 & 19,849 & 19,849 & 19,785 & 19,849 & 19,849 \\
\hline
\end{tabular}


Table 5

Environmental Scores and Institutional Investors: Deepwater Horizon Oil Spill

This table reports regression estimates of environmental scores on institutional ownership and control variables around the Deepwater Horizon oil spill that occurred on May 24, 2010. The dependent variables are the natural logarithm of environmental scores. The Post Event dummy is equal to one for the years 2011 and 2012 , and zero otherwise. In Panel A, we report within-industry results for firms in extracting industries. The coefficient estimate of Total IO $\times$ Post Event shows the differential effect of institutional ownership on environment scores after the event. In Panel B, we report difference-in-differences regression results. The coefficient estimate of Total IO $\times$ Post Event $\times$ Treated Firm shows the differential effect of institutional ownership on the environment scores for firms in extracting industries compare to the rest of the sample firms. The data are from the ASSET4 ESG database, Factset, and Worldscope. Appendix B and C describe the indicator variables used to calculate the various environmental and social scores. We winsorize all variables at the 1st and 99th percentiles. All right-hand side variables are lagged by one year. Standard errors are clustered at the country-level and $p$-values are reported in parentheses.

Panel A: Within-industry Results

\begin{tabular}{|c|c|c|c|c|c|}
\hline Environmental Score & Overall & Overall & Overall & Input-based & Output-based \\
\hline \multirow[t]{2}{*}{ Industry Definition } & $\begin{array}{l}\text { Oil and Gas } \\
\text { Extraction } \\
(\text { SIC 13) }\end{array}$ & $\begin{array}{c}\text { Mining } \\
(\text { SIC Division B) }\end{array}$ & $\begin{array}{l}\text { Oil, Gas, and } \\
\text { Coal Extraction } \\
\text { and Products } \\
(\mathrm{FF} 12)\end{array}$ & $\begin{array}{l}\text { Oil and Gas } \\
\text { Extraction } \\
\text { (SIC 13) }\end{array}$ & $\begin{array}{l}\text { Oil and Gas } \\
\text { Extraction } \\
(\text { SIC 13) }\end{array}$ \\
\hline & (1) & (2) & $(3)$ & (4) & (5) \\
\hline \multirow[t]{2}{*}{ Total $\mathrm{IO}_{\mathrm{t}-1}$} & 0.137 & 0.236 & 0.088 & 0.152 & -0.089 \\
\hline & $(0.14)$ & $(0.00)$ & $(0.24)$ & $(0.45)$ & $(0.02)$ \\
\hline \multirow[t]{2}{*}{ Post Event } & -0.007 & 0.013 & 0.014 & 0.048 & 0.007 \\
\hline & $(0.88)$ & $(0.64)$ & $(0.72)$ & $(0.84)$ & $(0.68)$ \\
\hline \multirow{2}{*}{ Total $\mathrm{IO}_{\mathrm{t}-1} \times$ Post Event } & 0.171 & 0.093 & 0.110 & 0.553 & 0.045 \\
\hline & $(0.02)$ & $(0.00)$ & $(0.04)$ & $(0.04)$ & $(0.30)$ \\
\hline \multirow[t]{2}{*}{ Log $(\text { Total Assets })_{t-1}$} & 0.264 & 0.224 & 0.254 & 0.562 & 0.007 \\
\hline & $(0.00)$ & $(0.00)$ & $(0.00)$ & $(0.00)$ & $(0.34)$ \\
\hline \multirow[t]{2}{*}{ Tangibility $_{\mathrm{t}-1}$} & -0.081 & -0.059 & -0.022 & -0.475 & -0.038 \\
\hline & $(0.57)$ & $(0.61)$ & $(0.87)$ & $(0.21)$ & $(0.07)$ \\
\hline \multirow[t]{2}{*}{ Leverage $_{\mathrm{t}-1}$} & -0.179 & -0.260 & -0.102 & -0.140 & 0.020 \\
\hline & $(0.32)$ & $(0.13)$ & $(0.49)$ & $(0.73)$ & $(0.47)$ \\
\hline \multirow[t]{2}{*}{ Tobin's q $\mathrm{t}-1$} & 0.012 & 0.012 & 0.017 & -0.084 & -0.000 \\
\hline & $(0.62)$ & $(0.11)$ & $(0.15)$ & $(0.04)$ & $(0.95)$ \\
\hline \multirow[t]{2}{*}{$\mathrm{ROA}_{\mathrm{t}-1}$} & -0.121 & -0.169 & -0.182 & -0.763 & 0.033 \\
\hline & $(0.76)$ & $(0.37)$ & $(0.65)$ & $(0.65)$ & $(0.37)$ \\
\hline Country Fixed Effects & Yes & Yes & Yes & Yes & Yes \\
\hline Year Fixed Effects & Yes & Yes & Yes & Yes & Yes \\
\hline Adjusted $R^{2}$ & 0.680 & 0.602 & 0.700 & 0.531 & 0.232 \\
\hline Obs & 478 & 1,280 & 704 & 478 & 478 \\
\hline
\end{tabular}


Panel B: Difference-in-Differences Regression Results (10,466 Observations)

\begin{tabular}{lccc}
\hline & \multicolumn{3}{c}{ Treatment Effect } \\
Environmental Score & $\begin{array}{c}\text { Oil and Gas Extraction } \\
\text { (SIC 13) }\end{array}$ & $\begin{array}{c}\text { Mining } \\
(\text { SIC Division B) }\end{array}$ & $\begin{array}{c}\text { Oil, Gas, and Coal } \\
\text { Extraction and Products } \\
(\text { FF12) }\end{array}$ \\
\cline { 2 - 4 } & $(1)$ & $(2)$ & $(4)$ \\
\hline Overall & 0.149 & 0.090 & 0.141 \\
& $(0.06)$ & $(0.17)$ & $(0.06)$ \\
Input-based & 0.539 & 0.240 & 0.415 \\
& $(0.01)$ & $(0.06)$ & $(0.00)$ \\
Output-based & 0.011 & -0.021 & 0.017 \\
& $(0.85)$ & $(0.32)$ & $(0.78)$ \\
\hline
\end{tabular}




\section{Table 6}

\section{Environmental and Social Scores and Institutional Ownership: Institutional Investor Types}

This table reports regression estimates of environmental and social scores on various types of institutional ownership and control variables. The dependent variables are the natural logarithm of the overall environmental and social scores. The data are from the ASSET4 ESG database, Factset, and Worldscope, and they are obtained for the years 2004-2013. Appendix B and C describe the indicator variables used to calculate the various environmental and social scores. Control variables are included but not reported. We winsorize all variables at the 1st and 99th percentiles. All right-hand side variables are lagged by one year. Standard errors are clustered at the country-level and $p$-values are reported in parentheses.

\begin{tabular}{|c|c|c|c|c|c|c|}
\hline & \multicolumn{3}{|c|}{ Overall Environmental Scores } & \multicolumn{3}{|c|}{ Overall Social Scores } \\
\hline & $(1)$ & $(2)$ & (3) & $(4)$ & $(5)$ & (6) \\
\hline IO Insurance Companies $_{t-1}$ & $\begin{array}{l}-0.284 \\
(0.60)\end{array}$ & & & $\begin{array}{l}0.011 \\
(0.97)\end{array}$ & & \\
\hline IO Investment Companies ${ }_{t-1}$ & $\begin{array}{l}-0.130 \\
(0.43)\end{array}$ & & & $\begin{array}{l}-0.017 \\
(0.83)\end{array}$ & & \\
\hline IO Investment Advisors ${ }_{t-1}$ & $\begin{array}{l}0.405 \\
(0.00)\end{array}$ & & & $\begin{array}{l}0.181 \\
(0.00)\end{array}$ & & \\
\hline IO Pension Funds ${ }_{t-1}$ & $\begin{array}{l}1.057 \\
(0.00)\end{array}$ & & & $\begin{array}{l}0.398 \\
(0.00)\end{array}$ & & \\
\hline IO Hedge Funds $\mathrm{t}_{-1}$ & $\begin{array}{l}-1.457 \\
(0.00)\end{array}$ & & & $\begin{array}{l}-0.430 \\
(0.06)\end{array}$ & & \\
\hline Domestic $\mathrm{IO}_{\mathrm{t}-1}$ & & $\begin{array}{l}0.448 \\
(0.00)\end{array}$ & $\begin{array}{l}0.446 \\
(0.00)\end{array}$ & & $\begin{array}{l}0.185 \\
(0.00)\end{array}$ & $\begin{array}{l}0.184 \\
(0.00)\end{array}$ \\
\hline Foreign $\mathrm{IO}_{\mathrm{t}-1}$ & & $\begin{array}{l}0.198 \\
(0.03)\end{array}$ & & & $\begin{array}{l}0.114 \\
(0.00)\end{array}$ & \\
\hline Foreign U.S. $\mathrm{IO}_{\mathrm{t}-1}$ & & & $\begin{array}{l}-0.136 \\
(0.28)\end{array}$ & & & $\begin{array}{l}0.037 \\
(0.51)\end{array}$ \\
\hline Foreign Non-U.S. $\mathrm{IO}_{\mathrm{t}-1}$ & & & $\begin{array}{l}0.772 \\
(0.00) \\
\end{array}$ & & & $\begin{array}{l}0.258 \\
(0.00) \\
\end{array}$ \\
\hline Control Variables Included & Yes & Yes & Yes & Yes & Yes & Yes \\
\hline Country Fixed Effects & Yes & Yes & Yes & Yes & Yes & Yes \\
\hline Industry Fixed Effects & Yes & Yes & Yes & Yes & Yes & Yes \\
\hline Year Fixed Effects & Yes & Yes & Yes & Yes & Yes & Yes \\
\hline Adjusted $R^{2}$ & 0.547 & 0.544 & 0.546 & 0.526 & 0.524 & 0.525 \\
\hline Obs & 19,849 & 19,849 & 19,849 & 19,849 & 19,849 & 19,849 \\
\hline
\end{tabular}


Table 7

Environmental and Social Scores and Institutional Ownership: Controlling for Transparency and Governance

This table reports regression estimates of environmental and social scores on institutional ownership, controlling for transparency scores, governance measures, and control variables. The dependent variables are the natural logarithm of environmental and social scores. The transparency score is the natural logarithm of the overall transparency score. Insider control is the residuals of a regression of Closely Held Shares (obtained from Datastream) on Total IO. The data are from the ASSET4 ESG database, Factset, and Worldscope, and they are obtained for the years 2004-2013. Appendix B and C describe the indicator variables used to calculate the various environmental and social scores. We winsorize all variables at the 1st and 99th percentiles. All right-hand side variables are lagged by one year. Standard errors are clustered at the country-level and $p$-values are reported in parentheses.

Panel A: Controlling for Transparency

\begin{tabular}{|c|c|c|c|c|c|c|c|c|}
\hline & \multicolumn{4}{|c|}{ Environmental Scores } & \multicolumn{4}{|c|}{ Social Scores } \\
\hline & $\begin{array}{l}\text { Overall } \\
\text { Score }\end{array}$ & $\begin{array}{l}\text { ASSET4 } \\
z \text {-Score }\end{array}$ & $\begin{array}{c}\text { Input-based } \\
\text { Score }\end{array}$ & $\begin{array}{c}\text { Output-based } \\
\text { Score }\end{array}$ & $\begin{array}{l}\text { Overall } \\
\text { Score }\end{array}$ & $\begin{array}{c}\text { ASSET4 } \\
z \text {-Score }\end{array}$ & $\begin{array}{c}\text { Input-based } \\
\text { Score }\end{array}$ & $\begin{array}{c}\text { Output-based } \\
\text { Score }\end{array}$ \\
\hline & (1) & $(2)$ & $(3)$ & (4) & $(5)$ & (6) & $(7)$ & $(8)$ \\
\hline \multirow[t]{2}{*}{ Total $\mathrm{IO}_{\mathrm{t}-1}$} & 0.170 & 0.256 & 0.398 & -0.004 & 0.083 & 0.315 & 0.301 & 0.010 \\
\hline & $(0.00)$ & $(0.00)$ & $(0.01)$ & $(0.78)$ & $(0.00)$ & $(0.00)$ & $(0.00)$ & $(0.16)$ \\
\hline \multirow[t]{2}{*}{ Log $(\text { Total Assets })_{t-1}$} & 0.161 & 0.186 & 0.318 & 0.016 & 0.060 & 0.189 & 0.166 & 0.010 \\
\hline & $(0.00)$ & $(0.00)$ & $(0.00)$ & $(0.00)$ & $(0.00)$ & $(0.00)$ & $(0.00)$ & $(0.00)$ \\
\hline \multirow{2}{*}{ Tangibility $_{\mathrm{t}-1}$} & 0.187 & 0.218 & 0.434 & -0.008 & -0.001 & 0.001 & 0.062 & -0.005 \\
\hline & $(0.00)$ & $(0.00)$ & $(0.00)$ & $(0.39)$ & $(0.96)$ & $(0.99)$ & $(0.29)$ & $(0.24)$ \\
\hline \multirow[t]{2}{*}{ Leverage $_{\mathrm{t}-1}$} & -0.081 & -0.093 & -0.147 & -0.008 & -0.001 & 0.011 & 0.011 & -0.001 \\
\hline & $(0.27)$ & $(0.37)$ & $(0.24)$ & $(0.46)$ & $(0.97)$ & $(0.90)$ & $(0.82)$ & $(0.82)$ \\
\hline \multirow[t]{2}{*}{ Tobin's q $\mathrm{t}-1_{1}$} & 0.030 & 0.022 & 0.030 & 0.009 & 0.012 & 0.020 & 0.032 & 0.003 \\
\hline & $(0.00)$ & $(0.01)$ & $(0.03)$ & $(0.00)$ & $(0.00)$ & $(0.19)$ & $(0.01)$ & $(0.00)$ \\
\hline \multirow[t]{2}{*}{$\mathrm{ROA}_{\mathrm{t}-1}$} & 0.021 & 0.110 & 0.126 & -0.046 & -0.040 & -0.017 & -0.099 & -0.008 \\
\hline & $(0.82)$ & $(0.37)$ & $(0.65)$ & $(0.00)$ & $(0.31)$ & $(0.91)$ & $(0.36)$ & $(0.37)$ \\
\hline \multirow[t]{2}{*}{ Transparency Score $_{t}$} & 3.314 & 4.149 & 5.775 & 0.198 & 3.322 & 11.593 & 7.910 & 0.442 \\
\hline & $(0.00)$ & $(0.00)$ & $(0.00)$ & $(0.00)$ & $(0.00)$ & $(0.00)$ & $(0.00)$ & $(0.00)$ \\
\hline Country Fixed Effects & Yes & Yes & Yes & Yes & Yes & Yes & Yes & Yes \\
\hline Industry Fixed Effects & Yes & Yes & Yes & Yes & Yes & Yes & Yes & Yes \\
\hline Year Fixed Effects & Yes & Yes & Yes & Yes & Yes & Yes & Yes & Yes \\
\hline Adjusted $R^{2}$ & 0.643 & 0.546 & 0.540 & 0.37 & 0.618 & 0.501 & 0.503 & 0.402 \\
\hline Obs & 19,849 & 19,785 & 19,849 & 19,849 & 19,849 & 19,785 & 19,849 & 19,849 \\
\hline
\end{tabular}


Panel B: Controlling for Insider Control

\begin{tabular}{|c|c|c|c|c|c|c|c|c|}
\hline & \multicolumn{4}{|c|}{ Environmental Scores } & \multicolumn{4}{|c|}{ Social Scores } \\
\hline & $\begin{array}{l}\text { Overall } \\
\text { Score }\end{array}$ & $\begin{array}{c}\text { ASSET4 } \\
z \text {-Score }\end{array}$ & $\begin{array}{c}\text { Input-based } \\
\text { Score }\end{array}$ & $\begin{array}{c}\text { Output-based } \\
\text { Score } \\
\end{array}$ & $\begin{array}{l}\text { Overall } \\
\text { Score }\end{array}$ & $\begin{array}{c}\text { ASSET4 } \\
z \text {-Score }\end{array}$ & $\begin{array}{c}\text { Input-based } \\
\text { Score }\end{array}$ & $\begin{array}{c}\text { Output-based } \\
\text { Score }\end{array}$ \\
\hline & $(1)$ & $(2)$ & $(3)$ & $(4)$ & $(5)$ & $(6)$ & $(7)$ & $(8)$ \\
\hline \multirow{2}{*}{ Total $\mathrm{IO}_{\mathrm{t}-1}$} & 0.270 & 0.382 & 0.573 & 0.003 & 0.125 & 0.465 & 0.395 & 0.015 \\
\hline & $(0.00)$ & $(0.00)$ & $(0.00)$ & $(0.79)$ & $(0.00)$ & $(0.00)$ & $(0.00)$ & $(0.04)$ \\
\hline \multirow[t]{2}{*}{$\log (\text { Total Assets })_{\mathrm{t}-1}$} & 0.213 & 0.251 & 0.408 & 0.019 & 0.085 & 0.275 & 0.227 & 0.014 \\
\hline & $(0.00)$ & $(0.00)$ & $(0.00)$ & $(0.00)$ & $(0.00)$ & $(0.00)$ & $(0.00)$ & $(0.00)$ \\
\hline \multirow{2}{*}{ Tangibility $_{\mathrm{t}-1}$} & 0.188 & 0.215 & 0.419 & -0.007 & 0.029 & 0.104 & 0.128 & -0.002 \\
\hline & $(0.00)$ & $(0.00)$ & $(0.00)$ & $(0.44)$ & $(0.19)$ & $(0.19)$ & $(0.06)$ & $(0.77)$ \\
\hline \multirow[t]{2}{*}{ Leverage $_{\mathrm{t}-1}$} & -0.102 & -0.122 & -0.170 & -0.009 & -0.032 & -0.094 & -0.062 & -0.005 \\
\hline & $(0.17)$ & $(0.26)$ & $(0.17)$ & $(0.38)$ & $(0.22)$ & $(0.38)$ & $(0.31)$ & $(0.46)$ \\
\hline \multirow[t]{2}{*}{ Tobin's q $\mathrm{t}-1$} & 0.034 & 0.027 & 0.043 & 0.009 & 0.016 & 0.036 & 0.046 & 0.003 \\
\hline & $(0.00)$ & $(0.00)$ & $(0.00)$ & $(0.00)$ & $(0.00)$ & $(0.01)$ & $(0.00)$ & $(0.00)$ \\
\hline \multirow[t]{2}{*}{$\mathrm{ROA}_{\mathrm{t}-1}$} & 0.084 & 0.181 & 0.210 & -0.040 & 0.070 & 0.359 & 0.163 & 0.008 \\
\hline & $(0.40)$ & $(0.15)$ & $(0.42)$ & $(0.00)$ & $(0.10)$ & $(0.04)$ & $(0.17)$ & $(0.38)$ \\
\hline \multirow{2}{*}{ Insider Control t-1 } & -0.101 & -0.116 & -0.181 & -0.021 & -0.028 & -0.071 & -0.110 & -0.002 \\
\hline & $(0.01)$ & $(0.03)$ & $(0.07)$ & $(0.00)$ & $(0.05)$ & $(0.15)$ & $(0.02)$ & $(0.55)$ \\
\hline Country Fixed Effects & Yes & Yes & Yes & Yes & Yes & Yes & Yes & Yes \\
\hline Industry Fixed Effects & Yes & Yes & Yes & Yes & Yes & Yes & Yes & Yes \\
\hline Year Fixed Effects & Yes & Yes & Yes & Yes & Yes & Yes & Yes & Yes \\
\hline Adjusted $R^{2}$ & 0.545 & 0.447 & 0.475 & 0.356 & 0.526 & 0.394 & 0.450 & 0.370 \\
\hline Obs & 18,560 & 18,496 & 18,560 & 18,560 & 18,560 & 18,496 & 18,560 & 18,560 \\
\hline
\end{tabular}


Panel C: Controlling for Transparency and Insider Control

\begin{tabular}{|c|c|c|c|c|c|c|c|c|}
\hline & \multicolumn{4}{|c|}{ Environmental Scores } & \multicolumn{4}{|c|}{ Social Scores } \\
\hline & $\begin{array}{l}\text { Overall } \\
\text { Score }\end{array}$ & $\begin{array}{l}\text { ASSET4 } \\
z \text {-Score }\end{array}$ & $\begin{array}{c}\text { Input-based } \\
\text { Score }\end{array}$ & $\begin{array}{c}\text { Output-based } \\
\text { Score } \\
\end{array}$ & $\begin{array}{l}\text { Overall } \\
\text { Score }\end{array}$ & $\begin{array}{c}\text { ASSET4 } \\
z \text {-Score }\end{array}$ & $\begin{array}{c}\text { Input-based } \\
\text { Score }\end{array}$ & $\begin{array}{c}\text { Output-based } \\
\text { Score }\end{array}$ \\
\hline & $(1)$ & $(2)$ & $(3)$ & $(4)$ & $(5)$ & (6) & $(7)$ & $(8)$ \\
\hline \multirow{2}{*}{ Total $\mathrm{IO}_{\mathrm{t}-1}$} & 0.184 & 0.274 & 0.423 & -0.002 & 0.082 & 0.316 & 0.294 & 0.009 \\
\hline & $(0.00)$ & $(0.00)$ & $(0.00)$ & $(0.88)$ & $(0.00)$ & $(0.00)$ & $(0.00)$ & $(0.22)$ \\
\hline \multirow[t]{2}{*}{$\log (\text { Total Assets })_{t-1}$} & 0.163 & 0.188 & 0.320 & 0.016 & 0.062 & 0.194 & 0.173 & 0.011 \\
\hline & $(0.00)$ & $(0.00)$ & $(0.00)$ & $(0.00)$ & $(0.00)$ & $(0.00)$ & $(0.00)$ & $(0.00)$ \\
\hline \multirow[t]{2}{*}{ Tangibility $_{\mathrm{t}-1}$} & 0.179 & 0.203 & 0.402 & -0.007 & -0.003 & -0.010 & 0.052 & -0.006 \\
\hline & $(0.00)$ & $(0.00)$ & $(0.00)$ & $(0.44)$ & $(0.83)$ & $(0.87)$ & $(0.34)$ & $(0.21)$ \\
\hline \multirow[t]{2}{*}{ Leverage $_{\mathrm{t}-1}$} & -0.064 & -0.074 & -0.102 & -0.007 & 0.006 & 0.040 & 0.028 & 0.000 \\
\hline & $(0.37)$ & $(0.47)$ & $(0.38)$ & $(0.51)$ & $(0.78)$ & $(0.66)$ & $(0.55)$ & $(0.98)$ \\
\hline \multirow[t]{2}{*}{ Tobin's q $\mathrm{t}-1$} & 0.033 & 0.025 & 0.040 & 0.009 & 0.013 & 0.023 & 0.037 & 0.003 \\
\hline & $(0.00)$ & $(0.00)$ & $(0.00)$ & $(0.00)$ & $(0.00)$ & $(0.12)$ & $(0.00)$ & $(0.00)$ \\
\hline \multirow[t]{2}{*}{$\mathrm{ROA}_{\mathrm{t}-1}$} & 0.009 & 0.087 & 0.078 & -0.045 & -0.031 & 0.005 & -0.074 & -0.005 \\
\hline & $(0.92)$ & $(0.46)$ & $(0.76)$ & $(0.00)$ & $(0.43)$ & $(0.98)$ & $(0.48)$ & $(0.60)$ \\
\hline \multirow{2}{*}{ Transparency Score $_{t}$} & 3.291 & 4.119 & 5.756 & 0.193 & 3.255 & 11.373 & 7.637 & 0.432 \\
\hline & $(0.00)$ & $(0.00)$ & $(0.00)$ & $(0.00)$ & $(0.00)$ & $(0.00)$ & $(0.00)$ & $(0.00)$ \\
\hline \multirow{2}{*}{ Insider Control t-1 $_{2}$} & -0.036 & -0.035 & -0.068 & -0.017 & -0.018 & -0.039 & -0.088 & -0.001 \\
\hline & $(0.25)$ & $(0.42)$ & $(0.44)$ & $(0.00)$ & $(0.12)$ & $(0.38)$ & $(0.04)$ & $(0.82)$ \\
\hline Country Fixed Effects & Yes & Yes & Yes & Yes & Yes & Yes & Yes & Yes \\
\hline Industry Fixed Effects & Yes & Yes & Yes & Yes & Yes & Yes & Yes & Yes \\
\hline Year Fixed Effects & Yes & Yes & Yes & Yes & Yes & Yes & Yes & Yes \\
\hline Adjusted $R^{2}$ & 0.643 & 0.546 & 0.540 & 0.371 & 0.616 & 0.497 & 0.503 & 0.400 \\
\hline Obs & 18,560 & 18,496 & 18,560 & 18,560 & 18,560 & 18,496 & 18,560 & 18,560 \\
\hline
\end{tabular}


Table 8

Environmental and Social Scores and Institutional Ownership: E\&S Measures from Sustainalytics

This table reports regression estimates of overall environmental and social scores obtained from Sustainalytics on institutional ownership and control variables. The data are from the Sustainalytics database, Factset, and Worldscope, and they are obtained for the years 2009-2013. We winsorize all variables at the 1st and 99th percentiles. All right-hand side variables are lagged by one year. Standard errors are clustered at the country-level and $p$-values are reported in parentheses.

\begin{tabular}{|c|c|c|}
\hline & Environmental & Social \\
\hline & (1) & (2) \\
\hline Total $\mathrm{IO}_{\mathrm{t}-1}$ & $\begin{array}{l}0.113 \\
(0.00)\end{array}$ & $\begin{array}{l}0.064 \\
(0.01)\end{array}$ \\
\hline $\log$ (Total Assets) $_{\mathrm{t}-1}$ & $\begin{array}{l}0.061 \\
(0.00)\end{array}$ & $\begin{array}{l}0.032 \\
(0.00)\end{array}$ \\
\hline Tangibility $_{t-1}$ & $\begin{array}{l}0.083 \\
(0.00)\end{array}$ & $\begin{array}{l}0.053 \\
(0.00)\end{array}$ \\
\hline Leverage $_{\mathrm{t}-1}$ & $\begin{array}{l}-0.103 \\
(0.00)\end{array}$ & $\begin{array}{c}-0.039 \\
(0.06)\end{array}$ \\
\hline Tobin's $\mathrm{q}_{\mathrm{t}-1}$ & $\begin{array}{l}0.011 \\
(0.13)\end{array}$ & $\begin{array}{l}0.006 \\
(0.22)\end{array}$ \\
\hline $\mathrm{ROA}_{\mathrm{t}-1}$ & $\begin{array}{r}0.019 \\
(0.75) \\
\end{array}$ & $\begin{array}{l}0.029 \\
(0.56) \\
\end{array}$ \\
\hline Country Fixed Effects & Yes & Yes \\
\hline Year Fixed Effects & Yes & Yes \\
\hline Industry Fixed Effects & Yes & Yes \\
\hline Adjusted $R^{2}$ & 0.427 & 0.322 \\
\hline Obs & 7,259 & 7,259 \\
\hline
\end{tabular}


Appendix A

Thomson Reuters ASSET4 Platform Screenshots of Opening Screen and Detail for Social Pillar

THOMSON REUTERS

ASSET4 Environmental, Social and Corporate Governance Data

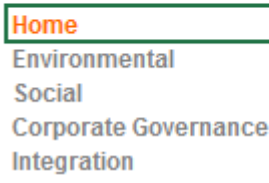




\section{ASSET4 Environmental, Social and Corporate Governance Data}

\begin{tabular}{|c|c|c|c|c|c|}
\hline $\begin{array}{l}\text { Home } \\
\text { Environmental } \\
\text { Social } \\
\text { Corporate Governance } \\
\text { Integration }\end{array}$ & \multicolumn{4}{|c|}{$\begin{array}{l}\text { COMPANY: BP plo } \\
\text { CURRENCY: USD }\end{array}$} & \multirow{2}{*}{2012} \\
\hline 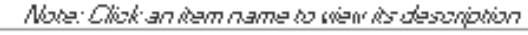 & 2008 & 2009 & 2010 & 2011 & \\
\hline \multicolumn{6}{|l|}{ Health \& Safety } \\
\hline Policy & Yes & Yes & Yes & Yes & Yes \\
\hline Total Iniury Rate & 2.15 & 1.7 & 3.05 & 1.8 & 1.75 \\
\hline Lost Time Injury Rate & 0.4 & 0.35 & 0.95 & 0.45 & 0.38 \\
\hline Lost Days & - & - & - & - & \\
\hline HIV-AIDS Programme & Yes & Yes & Yes & Yes & Yes \\
\hline \multicolumn{6}{|l|}{ Training \& Development } \\
\hline Policy & Yes & Yes & Yes & Yes & Yes \\
\hline Average Training Hours Per Employee & - & - & - & - & \\
\hline Training Costs Total & - & - & . & - & . \\
\hline Internal Promotion & Yes & Yes & Yes & Yes & Yes \\
\hline Management Training & Yes & Yes & Yes & Yes & Yes \\
\hline \multicolumn{6}{|l|}{ Diversity } \\
\hline Policy & YestYes & YestYes & YestYes & YestYes & Yestres \\
\hline Women Employees & - & - & - & $29 \%$ & $17 \%$ \\
\hline Women Managers & $22 \%$ & $23 \%$ & $24 \%$ & $25 \%$ & $25 \%$ \\
\hline Positive Discrimination & Yes & Yes & Yes & Yes & Yes \\
\hline Flexible Working Hours & Yes & Yes & Yes & Yes & Yes \\
\hline Day Care Services & No & No & No & No & No \\
\hline \multicolumn{6}{|l|}{ Human Rights } \\
\hline Policy & YestYes & YestYes & YestYes & YestYes & YestYes \\
\hline Human Rights Contractor & Yes & Yes & Yes & Yes & Yes \\
\hline Human Rights Breaches Contractor & Yes & Yes & Yes & Yes & Yes \\
\hline \multicolumn{6}{|l|}{ Community } \\
\hline Policy & YestYes & YestYes & Yest'Yes & Yest'Yes & Yest'Yes \\
\hline Donations Total & $125,600,000$ & $106,800,000$ & $115,200,000$ & $103,700,000$ & $90,600,000$ \\
\hline Cash Donations & - & - & - & - & \\
\hline In-KindDonations & - & - & - & - & \\
\hline Donations & Yes & Yes & Yes & Yes & Yes \\
\hline Crisis Management Systems & Yes & Yes & Yes & Yes & Yes \\
\hline \multicolumn{6}{|l|}{ Product Responsibility } \\
\hline Policy & YestYes & YestYes & YestYes & YestYes & Yestres \\
\hline Customer Satisfaction & - & - & - & - & . \\
\hline Product Access Low Price & Yes & Yes & No & No & No \\
\hline Healthy Food or Products & No & No & No & No & No \\
\hline
\end{tabular}




\section{Appendix B}

\section{Creating Environmental Indicator Variables Based on ASSET4 ESG Environmental Indicator Values}

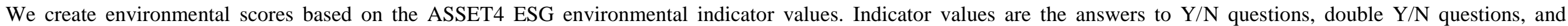

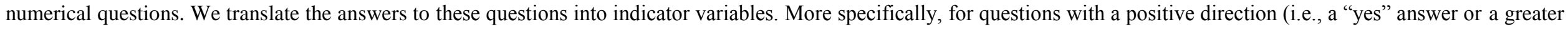

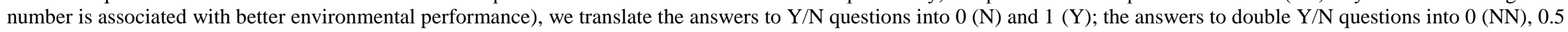

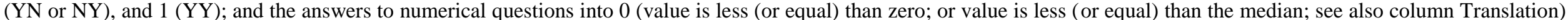

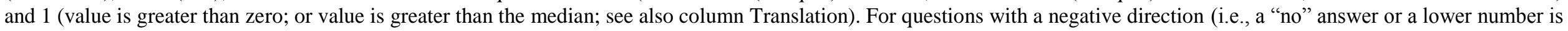

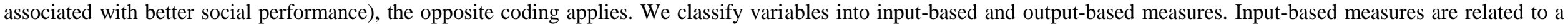
firm's policies and processes in place and the firm's disclosure of such policies and processes. Output-based measures are related to a firm's outputs and actions.

\begin{tabular}{|c|c|c|c|c|c|}
\hline Variable & Description & $\begin{array}{l}\text { Input/ } \\
\text { Output- } \\
\text { based }\end{array}$ & Direction & $\begin{array}{l}\text { Question } \\
\text { Type }\end{array}$ & $\begin{array}{c}\text { Translation } \\
\text { Numeric } \\
\text { Values }\end{array}$ \\
\hline
\end{tabular}

\section{A. Emission Reduction}

1) Biodiversity Controversies

Is the company under the spotlight of the media because of a controversy linked to biodiversity?

2) Biodiversity Impact

Does the company report on initiatives to protect, restore or reduce its impact on native ecosystems and species, biodiversity, protected and sensitive areas?

3) Cement $\mathrm{CO} 2$

Total $\mathrm{CO} 2$ and $\mathrm{CO} 2$ equivalents emission in kilograms per tonne of cement produced. Emissions

4) Climate Change Risks Is the company aware that climate change can represent commercial risks and/or opportunities? and Opportunities

5) $\mathrm{CO} 2$ Reduction

\section{System}

7) Environmental Compliance

8) Environmental Expenditures

9) Environmental Management Systems

10) Environmental Partnerships

11) Environmental Restoration Initiatives

Does the company show an initiative to reduce, reuse, recycle, substitute, phased out or compensate $\mathrm{CO} 2$ equivalents in the production process?

Total weight of water pollutant emissions in tonnes divided by net sales or revenue in US dollars.

All real or estimated penalties, fines from lost court cases, settlements or cases not yet settled regarding environmental controversies in US dollars.

Does the company report on its environmental expenditures or does the company report to make proactive environmental investments to reduce future risks or increase future opportunities?

The percentage of company sites or subsidiaries that are certified with any environmental management system.

Does the company report on partnerships or initiatives with specialized NGOs, industry organizations, governmental or supragovernmental organizations that focus on improving environmental issues?

Initiatives environment? 12) F-Gases Emissions $\quad$ Does the company report on initiatives to recycle, reduce, reuse or phase out fluorinated gases such as
HFCs (hydrofluorocarbons), PFCs (perfluorocarbons) or SF6 (sulphur hexafluoride)? 
13) Greenhouse Gas Emissions

14) Hazardous Waste

15) Implementation

16) Improvements

17) Innovative Production

18) Monitoring

19) NOx and SOx Emissions Reduction

20) Ozone-Depleting Substances Reduction

21) Policy

22) Spill Impact Reduction

23) Spills and Pollution Controversies

Total amount of hazardous waste produced in tonnes divided by net sales or revenue in US dollars. Does the company describe the implementation of its emission reduction policy through a public commitment from a senior management or board member? AND Does the company describe the implementation of its emission reduction policy through the processes in place?

Does the company set specific objectives to be achieved on emission reduction? impact during the production process? OR Does the company report on its participation in any emissions trading initiative? OR Does the company report on new production techniques to improve the global environmental impact (all emissions) during the production process?

Does the company monitor its emission reduction performance?

Does the company report on initiatives to reduce, reuse, recycle, substitute, or phase out SOx (sulphur oxides) or NOx (nitrogen oxides) emissions?

Does the company report on initiatives to reduce, substitute, or phase out ozone-depleting (CFC-11 equivalents, chlorofluorocarbon) substances?

Does the company have a policy for reducing environmental emissions or its impacts on biodiversity? AND Does the company have a policy for maintaining an environmental management system?

Does the company report on initiatives to reduce
polluting events (crisis management system)?

Is the company directly or indirectly (through a supplier) under the spotlight of the media because of a controversy linked to the spill of chemicals, oils and fuels, gases (flaring) or controversy relating to the overall impacts of the company on the environment?

24) Transportation Impact Does the company report on initiatives to reduce the environmental impact of transportation of its Reduction

25) VOC Emissions Reduction products or its staff?

26) Waste

Does the company report on initiatives to reduce, substitute, or phase out volatile organic compounds (VOC) or particulate matter less than ten microns in diameter (PM10)?

Total amount of waste produced in tonnes divided by net sales or revenue in US dollars.

27) Waste Recycling Ratio Total recycled and reused waste produced in tonnes divided by total waste produced in tonnes.

28) Waste Reduction

Does the company report on initiatives to recycle, reduce, reuse, substitute, treat or phase out total waste, hazardous waste or wastewater?

Number of input-based variables Number of output-based variables
Positive

$\mathrm{Y} / \mathrm{N}$

I Positive

$\mathrm{Y} / \mathrm{N}$

Positive $\quad \mathrm{Y} / \mathrm{N}$

I Positive $\mathrm{Y} / \mathrm{N}$

I Positive $\mathrm{Y} / \mathrm{N}$

Positive Double Y/N

I Positive $\mathrm{Y} / \mathrm{N}$

O Negative $\mathrm{Y} / \mathrm{N}$

Positive $\mathrm{Y} / \mathrm{N}$

Positive $\quad \mathrm{Y} / \mathrm{N}$

Negative Number Median

Positive Number Median

Positive Y/N

\section{B. Product Innovation}

1) Animal Testing

Is the company endorsing guidelines on animal testing (e.g., the EU guideline on animal experiments)?

OR Has the company established a programme or an initiative to reduce, phase out or substitute for animal testing?

2) Eco-Design Products Does the company report on specific products which are designed for reuse, recycling or the reduction of 
3) Energy Footprint Reduction

4) Environmental Asse Management

5) Environmental Labels and Awards

6) Environmental Products

7) Environmental Project Financing

8) Environmental R\&D Expenditures

10) GMO Free Products

11) Hybrid Vehicles

12) Implementation

13) Improvements

14) Labelled Wood Percentage

15) Liquefied Natural Ga

16) Monitoring

17) Noise Reduction

18) Organic Products

19) Policy

20) Product Impact Controversies

21) Product Impact Minimization

22) Renewable Energy environmental impacts?

Does the company describe initiatives in place to reduce the energy footprint of its products during their use?

Does the company report on assets under management which employ environmental screening criteria or environmental factors in the investment selection process?

Has the company received product awards with respect to environmental responsibility? OR Does the company use product labels (e.g., FSC, Energy Star, MSC) indicating the environmental responsibility of its products?

Does the company report on at least one product line or service that is designed to have positive effects on the environment or which is environmentally labelled and marketed?

Is the company a signatory of the Equator Principles (commitment to manage environmental issues in project financing)? OR Does the company claim to evaluate projects on the basis of environmental or biodiversity risks as well?

Does the company invest in R\&D on new environmentally friendly products or services that will limit the amount of emissions and resources needed during product use?

Total amount of environmental R\&D costs (without clean up and remediation costs) divided by net sales or revenue in US dollars.

Does the company make a commitment to exclude GMO ingredients from its products or retail offerings?

Is the company developing hybrid vehicles?

Does the company describe the implementation of its environmental product innovation policy?

Does the company set specific objectives to be achieved on environmental product innovation?

The percentage of labelled wood or forest products (e.g., Forest Stewardship Council (FSC)) from total wood or forest products.

Does the company develop new products and services linked to liquefied natural gas?

Does the company describe, claim to have or mention the processes it uses to accomplish environmental product innovation?

Does the company develop new products that are marketed as reducing noise emissions?

Does the company report or show initiatives to produce or promote organic food or other products?

Does the company have an environmental product innovation policy (eco-design, life cycle assessment, dematerialization)?

Is the company under the spotlight of the media because of a controversy linked to the environmental impact of its products or services?

Does the company reports about take-back procedures and recycling programmes to reduce the potential risks of products entering the environment? OR Does the company report about product features and applications or services that will promote responsible, efficient, cost-effective and environmentally preferable use?

Total energy distributed or produced from renewable energy sources divided by the total energy
Positive

$\mathrm{Y} / \mathrm{N}$

Positive

$\mathrm{Y} / \mathrm{N}$

O Positive

$\mathrm{Y} / \mathrm{N}$

Positive $\quad \mathrm{Y} / \mathrm{N}$

I Positive

$\mathrm{Y} / \mathrm{N}$

Positive

$\mathrm{Y} / \mathrm{N}$

Positive Number

Median

Positive Y/N

Positive $\quad \mathrm{Y} / \mathrm{N}$

Positive $\quad \mathrm{Y} / \mathrm{N}$

Positive Y/N

Positive Number

Median

Positive $\quad \mathrm{Y} / \mathrm{N}$

Positive $\quad \mathrm{Y} / \mathrm{N}$

Positive $\quad \mathrm{Y} / \mathrm{N}$

Positive Y/N

Positive $\quad \mathrm{Y} / \mathrm{N}$

O Negative $\mathrm{Y} / \mathrm{N}$

I Positive

Y/N 
Supply

23) Renewable/Clean Energy Products

24) Sustainable Building Products

25) Water Technologies distributed or produced.

Does the company develop products or technologies for use in the clean, renewable energy (such as wind, solar, hydro and geo-thermal and biomass power)?

Does the company develop products and services that improve the energy efficiency of buildings?

Does the company develop products or technologies that are used for water treatment, purification or that improve water use efficiency?
O Positive Y/N

O Positive Y/N

O Positive Y/N

Number of input-based variables 12 Number of output-based variables

C. Resource Reduction

1) Cement Energy Use

2) Energy Efficiency Initiatives

3) Energy Use

4) Environmental Resource Impact Controversies

Total energy use in gigajoules per tonne of clinker produced.

Does the company report on initiatives to use renewable energy sources? AND Does the company report on initiatives to increase its energy efficiency overall?

Total direct and indirect energy consumption in gigajoules divided by net sales or revenue in US dollars. Is the company under the spotlight of the media because of a controversy linked to the environmental impact of its operations on natural resources or local communities?

5) Environmental Supply Does the company use environmental criteria (ISO 14000, energy consumption, etc.) in the selection Chain Management

6) Green Buildings

7) Implementation

8) Improvements

9) Land Use

10) Materials a partnership with a sourcing partner, if environmental criteria are not met?

Does the company have environmentally friendly or green sites or offices?

Does the company describe the implementation of its resource efficiency policy through a public commitment from a senior management or board member? AND Does the company describe the implementation of its resource efficiency policy through the processes in place?

Does the company set specific objectives to be achieved on resource efficiency? AND Does the company comment on the results of previously set objectives?

Does the company report on initiatives to reduce the environmental impact on land owned, leased or managed for production activities or extractive use?

Total amount of materials used in tonnes divided by net sales or revenue in US dollars.

11) Materials Recycled and The percentage of recycled materials of the total materials used. Reused Ratio

12) Monitoring

13) Policy

Does the company monitor its resource efficiency performance?

Does the company have a policy for reducing the use of natural resources? AND Does the company have a policy to lessen the environmental impact of its supply chain?

14) Renewable Energy Use Total energy generated from primary renewable energy sources divided by total energy.

15) Toxic Chemicals Does the company report on initiatives to reduce, reuse, substitute or phase out toxic chemicals or substances?

\begin{tabular}{|c|c|c|c|}
\hline $\mathrm{O}$ & Negative & Number & Median \\
\hline I & Positive & Double Y/N & \\
\hline $\mathrm{O}$ & Negative & Number & Median \\
\hline $\mathrm{O}$ & Negative & $\mathrm{Y} / \mathrm{N}$ & \\
\hline I & Positive & Double $\mathrm{Y} / \mathrm{N}$ & \\
\hline $\mathrm{O}$ & Positive & $\mathrm{Y} / \mathrm{N}$ & \\
\hline I & Positive & Double $\mathrm{Y} / \mathrm{N}$ & \\
\hline I & Positive & Double $\mathrm{Y} / \mathrm{N}$ & \\
\hline I & Positive & $\mathrm{Y} / \mathrm{N}$ & \\
\hline $\mathrm{O}$ & Negative & Number & Median \\
\hline $\mathrm{O}$ & Positive & Number & Median \\
\hline I & Positive & $\mathrm{Y} / \mathrm{N}$ & \\
\hline I & Positive & Double $\mathrm{Y} / \mathrm{N}$ & \\
\hline $\mathrm{O}$ & Positive & Number & Median \\
\hline I & Positive & $\mathrm{Y} / \mathrm{N}$ & \\
\hline
\end{tabular}


16) Water Recycling

17) Water Use
Does the company report on initiatives to reuse or recycle water? OR Does the company report on initiatives to reduce the amount of water used?

Total water withdrawal in cubic meters divided by net sales or revenue in US dollars.
I Positive $\mathrm{Y} / \mathrm{N}$

O Negative Number Median

Number of input-based variables 


\section{Appendix C}

\section{Creating Social Indicator Variables Based on ASSET4 ESG Social Indicator Values}

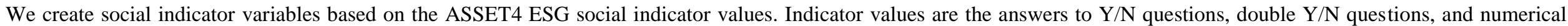

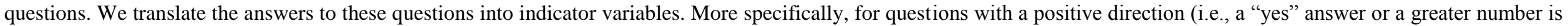

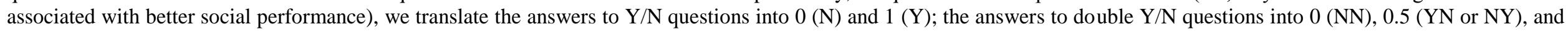

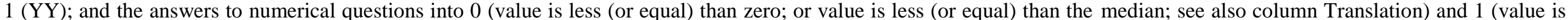

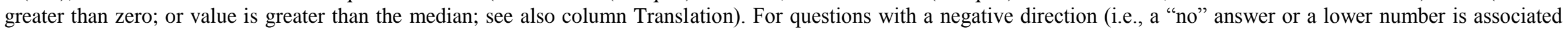

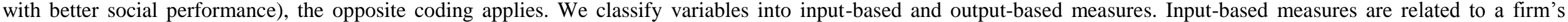
policies and processes in place and the firm's disclosure of such policies and processes. Output-based measures are related to a firm's outputs and actions.

\begin{tabular}{|c|c|c|}
\hline \multicolumn{2}{|c|}{$\begin{array}{l}\text { Input/ } \\
\text { Indicator Values } \quad \text { Descrintion/Ouestion }\end{array}$} & $\begin{array}{c}\text { Input/ } \\
\text { Output- } \\
\text { based }\end{array}$ \\
\hline
\end{tabular}

\section{A. Community Category}

1) Bribery, Corruption, Fraud Controversies

2) Business Ethics Compliance

3) Corporate Responsibility Awards

4) Crisis Management

5) Critical Countries, Indigenous People Controversies

6) Donations in General

7) Implementation

8) Improvements

9) Income Taxes

10) Monitoring

11) Patent Infringement
Is the company under the spotlight of the media because of a controversy linked to bribery and corruption, political contributions, improper lobbying, money laundering, parallel imports or any tax fraud?

All real or estimated penalties, fines from lost court cases, settlements or cases not yet settled regarding controversies linked to business ethics in general, political contributions or bribery and corruption, pricefixing or anti-competitive behaviour, tax fraud, parallel imports or money laundering in US dollars.

Has the company received an award for its social, ethical, community, or environmental activities or performance?

Does the company report on crisis management systems or reputation disaster recovery plans to reduce or minimize the effects of reputation disasters?

Is the company under the spotlight of the media because of a controversy linked to activities in critical, undemocratic countries that do not respect fundamental human rights or to disrespecting the rights of indigenous people?

Does the company make cash donations? AND Does the company make in-kind donations, foster employee engagement in voluntary work or provide funding of community-related projects through a corporate foundation?

Does the company describe the implementation of its community policy through a public commitment from a senior management or board member? AND Does the company describe the implementation of its community policy through the processes in place?

Does the company set specific objectives to be achieved on its reputation or its relations with communities?

Total amount of income taxes divided by net income.

Does the company monitor its reputation or its relations with communities?

All real or estimated penalties, fines from lost court cases, settlements or cases not yet settled regarding

\section{O Negative $\quad \mathrm{Y} / \mathrm{N}$}

O Negative Number

Zero

O Positive $\quad \mathrm{Y} / \mathrm{N}$

I Positive Y/N

$\mathrm{O} \quad$ Negative $\mathrm{Y} / \mathrm{N}$

Positive Double Y/N

I Positive Double $\mathrm{Y} / \mathrm{N}$

I Positive $\mathrm{Y} / \mathrm{N}$

O Positive Number Median

I Positive $\mathrm{Y} / \mathrm{N}$

O Negative Number Zero 
12) Policy

13) Public Health Controversies

14) Total Donations controversies linked to patents and intellectual property infringement in US dollars.

Does the company have a policy to strive to be a good corporate citizen or endorse the Global Sullivan Principles? AND Does the company have a policy to respect business ethics or has the company signed the UN Global Compact or follow the OECD guidelines?

Is the company under the spotlight of the media because of a controversy linked to public health or industrial accidents harming the health \& safety of third parties (non-employees and non-customers)?

Total amount of all donations divided by net sales or revenue.

\section{Positive Double Y/N}

O Negative $\quad \mathrm{Y} / \mathrm{N}$

O Positive Number

Number of input-based variables Number of output-based variables

B. Diversity and Opportunity

1) Diversity Compliance All real or estimated penalties, fines from lost court cases, settlements or cases not yet settled regarding controversies linked to workforce diversity and opportunity in US dollars.

2) Diversity Controversies

3) Family Friendly

4) Implementation

5) Improvements

6) Management Equal Opportunity

7) Managers Female Male Ratio

8) Monitoring

9) Policy

10) Work-Life Balance Is the company under the spotlight of the media because of a controversy linked to workforce diversity and opportunity?

Does the company claim to provide day care services for its employees? OR Does the company claim to provide generous maternity leave benefits? OR Has the company won a family friendly prize like a

\section{"Working Mother Award"?}

Does the company describe the implementation of its diversity and opportunity policy?

Does the company set specific objectives to be achieved on diversity and equal opportunity?

Does the company promote positive discrimination? OR Has the company won any prize or award relating to diversity or opportunity?

Percentage of women managers.

Does the company monitor the diversity and equal opportunities in its workforce?

Does the company have a work-life balance policy? AND Does the company have a diversity and equal opportunity policy?

Does the company claim to provide generous vacations, career breaks or sabbaticals? OR Does the company claim to provide flexible working hours or working hours that promote a work-life balance?
$\mathrm{O}$

Negative Number

Zero

$\begin{array}{ccc}\text { O } & \text { Negative } & \mathrm{Y} / \mathrm{N} \\ \mathrm{O} & \text { Positive } & \mathrm{Y} / \mathrm{N} \\ & & \\ \mathrm{I} & \text { Positive } & \mathrm{Y} / \mathrm{N} \\ \mathrm{I} & \text { Positive } & \mathrm{Y} / \mathrm{N} \\ \mathrm{O} & \text { Positive } & \mathrm{Y} / \mathrm{N} \\ & & \end{array}$

O Positive Number

Median

I Positive $\mathrm{Y} / \mathrm{N}$

I Positive Double $\mathrm{Y} / \mathrm{N}$

O Positive $\mathrm{Y} / \mathrm{N}$
Number of input-based variables Number of output-based variables
4

C. Employment Quality

1) Announced Lay-offs Total number of announced lay-offs by the company divided by the total number of employees.

2) Bonus Plan Does the company claim to provide a bonus plan to at least the middle management level? AND Is the employees' compensation based on personal or company-wide targets?

$\begin{array}{cccc}\text { O } & \text { Negative } & \text { Number } & \text { Median } \\ \text { O } & \text { Positive } & \text { Double Y/N } & \end{array}$


3) Employment Awards Has the company won an award or any prize related to general employment quality or "Best Company to Work For"?

4) Generous Fringe Benefits

5) Implementation

6) Improvements

7) Key Management Departures

8) Monitoring

9) Net Employment Creation

10) Personnel Turnover

11) Policy

12) Salaries

13) Salaries Distribution

14) Salary Gap

15) Strikes

16) Trade Union Representation

17) Wages or Working Condition

Controversies

Does the company claim to provide its employees with a pension fund, health care or other insurances?

Does the company describe the implementation of its employment quality policy?

Does the company set specific objectives to be achieved on employment quality?

Has an important executive management team member or a key team member announced a voluntary departure (other than for retirement) or has been ousted?

Does the company monitor or measure its performance on employment quality?

Employment growth over the last year.

Percentage of employee turnover.

Does the company have a competitive employee benefits policy or ensuring good employee relations within its supply chain? AND Does the company have a policy for maintaining long term employment growth and stability?

Average salaries and benefit in US dollars (Salaries and Benefits (US dollars) /Total Number of Employees).

Total salaries and benefits divided by net sales or revenue.

CEO's total salary (or other highest salary) divided by average wage (Highest Salary (US dollars) /Average Salaries and Benefits in (US dollars) ).

Has there has been a strike or an industrial dispute that led to lost working days?

Percentage of employees represented by independent trade union organizations or covered by collective bargaining agreements.

Is the company under the spotlight of the media because of a controversy linked to the company's employees, contractors or suppliers due to wage, layoff disputes or working conditions?

Number of input-based variables Number of output-based variables
Positive

D. Health and Safety

\begin{tabular}{|c|c|c|c|c|c|c|}
\hline 1) & $\begin{array}{l}\text { Health \& Safety } \\
\text { Compliance }\end{array}$ & $\begin{array}{l}\text { All real or estimated penalties, fines from lost court cases, settlements or cases not yet settled regarding } \\
\text { controversies linked to workforce or contractor health and safety in US dollars. }\end{array}$ & $\mathrm{O}$ & Negative & Number & Zero \\
\hline 2) & $\begin{array}{l}\text { Health \& Safety } \\
\text { Controversies }\end{array}$ & $\begin{array}{l}\text { Is the company under the spotlight of the media because of a controversy linked to workforce health and } \\
\text { safety? }\end{array}$ & $\mathrm{O}$ & Negative & $\mathrm{Y} / \mathrm{N}$ & \\
\hline 3) & HIV-AIDS Programme & Does the company report on policies or programmes on HIV/AIDS for the workplace or beyond? & I & Positive & $\mathrm{Y} / \mathrm{N}$ & \\
\hline 4) & Implementation & Does the company describe the implementation of its employee health \& safety policy through a public & I & Positive & Double Y/N & \\
\hline
\end{tabular}


5) Improvements

6) Injuries

7) Lost Days

8) Monitoring

9) Policy policy through the processes in place?

Does the company set specific objectives to be achieved on employee health \& safety? AND Does the company comment on the results of previously set objectives?

Total number of injuries and fatalities including no-lost-time injuries relative to one million hours worked.

Total lost days at work divided by total working days. (Refers to an employee absent from work because of incapacity of any kind, not just as the result of occupational injury or disease)

Does the company monitor or measure its performance on employee health \& safety?

Does the company have a policy to improve employee health \& safety within the company and its supply chain?

Number of input-based variables Number of output-based variables

\section{Positive Double $\mathrm{Y} / \mathrm{N}$}

O Negative Number

Median

O Negative Number

Median

Positive Y/N

Positive Y/N 4

E. Human Rights

1) Child Labour Controversies

2) Freedom of Association Controversies

3) Human Rights Controversies

4) Implementation

5) Improvements

6) Monitoring

7) Policy

8) Suppliers Social Impact
Is the company under the direct or indirect (through suppliers) spotlight of the media because of a controversy linked to child labour?

Is the company under the direct or indirect (through suppliers) spotlight of the media because of a controversy linked to freedom of association?

Is the company under the direct or indirect (through suppliers) spotlight of the media because of a controversy linked to general human rights issues?

Does the company describe the implementation of its human rights policy?

Does the company set specific objectives to be achieved on its human rights policy?

Does the company monitor human rights in its or its suppliers' facilities?

Does the company have a policy to guarantee the freedom of association universally applied independent of local laws? AND Does the company have a policy for the exclusion of child, forced or compulsory labour?

Does the company report or show to use human rights criteria in the selection or monitoring process of its suppliers or sourcing partners? AND Does the company report or show to be ready to end a partnership with a sourcing partner if human rights criteria are not met?
Number of input-based variables Number of output-based variables
O

Negative

$\mathrm{Y} / \mathrm{N}$

O Negative

\section{$\mathrm{Y} / \mathrm{N}$}

O Negative $\mathrm{Y} / \mathrm{N}$

Positive $\quad \mathrm{Y} / \mathrm{N}$

Positive $\quad \mathrm{Y} / \mathrm{N}$

Positive $\quad \mathrm{Y} / \mathrm{N}$

Positive Double $\mathrm{Y} / \mathrm{N}$

Positive Double Y/N

5

F. Product Responsibility

\begin{tabular}{ll}
\hline 1) Customer & Is the company under the spotlight of the media because of a controversy linked to its products or \\
Controversies & services quality and responsibility?
\end{tabular}

\section{Controversies} services quality and responsibility?

2) Implementation

$\begin{array}{lll}\text { O } & \text { Negative } & \text { Y/N } \\ \text { I } & \text { Positive } & \text { Y/N }\end{array}$


3) Improvements

4) Monitoring

5) Policy

6) Product Access

7) Product Compliance

8) Quality Management

9) Social Exclusion Controversies

10) Technology KnowHow Sharing
Does the company set specific objectives to be achieved on its products or services quality and responsibility?

Does the company monitor the impact of its products or services on consumers or the community more generally?

Does the company have a policy to protect customer health \& safety? AND Does the company have a products and services quality policy?

Does the company distribute any low-priced products or services specifically designed for lower income categories (e.g., bridging the digital divide, telecommunications, low cost cars and micro-financing services)?

All real or estimated penalties, fines from lost court cases, settlements or cases not yet settled regarding controversies linked its products or services quality and responsibility in US dollars.

Does the company claim to apply quality management systems, such as ISO 9000, Six Sigma, Lean Manufacturing, Lean Sigma, TQM or any other similar quality principles?

Is the company under the spotlight of the media because of a controversy linked to market withdrawal (closing of branches), retreating or failing to serve specific markets or customers?O

Does the company voluntarily share licenses, patents, intellectual property or useful technology with developing countries, or allow generics under specific conditions?

Number of input-based variables

I Positive $\mathrm{Y} / \mathrm{N}$

I Positive $\mathrm{Y} / \mathrm{N}$

Positive Double $\mathrm{Y} / \mathrm{N}$

$\mathrm{O}$

Positive

$\mathrm{Y} / \mathrm{N}$

O Negative Number

Zero

O Positive $\mathrm{Y} / \mathrm{N}$

O Negative $\mathrm{Y} / \mathrm{N}$

O Positive $\mathrm{Y} / \mathrm{N}$

G. Training and Development

\begin{tabular}{|c|c|c|c|c|c|c|}
\hline 1) & Implementation & Does the company describe the implementation of its training and development policy? & I & Positive & $\mathrm{Y} / \mathrm{N}$ & \\
\hline 2) & Improvements & $\begin{array}{l}\text { Does the company set specific objectives to be achieved on the employee training and career } \\
\text { development? }\end{array}$ & I & Positive & $\mathrm{Y} / \mathrm{N}$ & \\
\hline 3) & Internal Promotion & Does the company claim to favour promotion from within? & $\mathrm{O}$ & Positive & $\mathrm{Y} / \mathrm{N}$ & \\
\hline 4) & Management Training & Does the company claim to provide regular staff and business management training for its managers? & $\mathrm{O}$ & Positive & $\mathrm{Y} / \mathrm{N}$ & \\
\hline 5) & Monitoring & Does the company monitor its training and development programs? & I & Positive & $\mathrm{Y} / \mathrm{N}$ & \\
\hline 6) & Policy & Does the company have a policy to support the skills training or career development of its employees? & I & Positive & $\mathrm{Y} / \mathrm{N}$ & \\
\hline 7) & Supplier ESG Training & Does the company provide training on environmental, social or governance factors for its suppliers? & $\mathrm{O}$ & Positive & $\mathrm{Y} / \mathrm{N}$ & \\
\hline 8) & Training Costs & Training costs per employee in US dollars. & $\mathrm{O}$ & Positive & Number & Median \\
\hline 9) & Training Hours & Average hours of training per year per employee. & $\mathrm{O}$ & Positive & Number & Median \\
\hline \multirow[t]{2}{*}{ 10) } & University Partnerships & Does the company claim to cooperate with schools or universities? & $\mathrm{O}$ & Positive & $\mathrm{Y} / \mathrm{N}$ & \\
\hline & & $\begin{array}{l}\text { Number of input-based variables } \\
\text { Number of output-based variables }\end{array}$ & $\begin{array}{l}4 \\
6\end{array}$ & & & \\
\hline
\end{tabular}

